\title{
Maternal thyroid dysfunction affects placental profile of inflammatory mediators and the intrauterine trophoblast migration kinetics
}

\author{
Juneo Freitas Silva, Natália Melo Ocarino and Rogéria Serakides \\ Departamento de Clínica e Cirurgia Veterinária, Escola de Veterinária, Universidade Federal de Minas Gerais, \\ Av. Antônio Carlos, 6627, 31270-901 Belo Horizonte, Minas Gerais, Brazil \\ Correspondence should be addressed to R Serakides; Email: serakidesufmg@gmail.com
}

\begin{abstract}
The objective of the present study was to evaluate the gene and immunohistochemical expression of inflammatory mediators involved in the immune activity and the intrauterine trophoblast migration of the placentas in hypothyroid and L-thyroxine (L-T $)_{4}$-treated rats. A total of 144 adult female rats were divided equally into hypothyroid, $\mathrm{L}_{\mathbf{4}}$-treated, and euthyroid (control) groups. Hypothyroidism was induced by daily administration of propylthiouracil. Rats were killed at 0, 10, 14, 15, 16, 17, 18, and 19 days of gestation. We evaluated the depth of interstitial and endovascular intrauterine trophoblast invasion and the immunohistochemical expression of interferon $\gamma$ (INFy), migration inhibitory factor (MIF), and inducible nitric oxide synthase (NOS2 (iNOS)). The gene expression of Toll-like receptor 2 (TIr2) and TIr4, Infy, Mif, tumor necrosis factor (Tnf (Tnf $\alpha)$ ), II10, Nos2, matrix metalloproteinase 2 (Mmp2) and Mmp9, and placental leptin was also measured in placental disks by real-time RT-PCR. The data were analyzed using an Student-Newman-Keuls (SNK) test. Hypothyroidism reduced the endovascular and interstitial trophoblast migration, and the expression of TLR4, INFy, MIF, interleukin 10 (IL10), NOS2, MMP2 and MMP9, and placental leptin, while increased the expression of TLR2 $(P<0.05)$. $T_{4}$-treated rats not only increased the expression of IL10 and NOS2 but also reduced the expression of TNF and MIF at 10 days of gestation $(P<0.05)$. However, at 19 days of gestation, expression of INFy and MIF was increased in $T_{4}$-treated group $(P<0.05)$. Excess of $T_{4}$ also increased the gene expression of $\mathbf{M m p 2}$ at 10 days of gestation $(P<0.05)$, but reduced the endovascular trophoblast migration at 18 days of gestation $(P<0.05)$. Hypothyroidism and excess of $T_{4}$ differentially affect the immune profile and the intrauterine trophoblast migration of the placenta, and these effects are dependent on the gestational period.

Reproduction (2014) 147 803-816
\end{abstract}

\section{Introduction}

The maternal immune response and the migration of trophoblast cells in the maternal-fetal interface are critical determinants of the success or failure of pregnancy in both humans and rodents (Koga et al. 2009, Hammer 2011). Changes in the pro- and antiinflammatory cytokines in the maternal-fetal interface and placentation failure due to extensive trophoblastic invasion or superficial trophoblastic invasion can cause miscarriage, premature birth, intrauterine growth restriction, and pre-eclampsia in women as well as in experimental animal models (Coulam 2000, Toder et al. 2003, Zhang et al. 2007, Koga et al. 2009, Hammer 2011, Soares et al. 2012). Therefore, basic research in this area has attempted to evaluate the molecular mechanisms that control the placental immune system and the trophoblast invasion in physiological and pathological conditions (Rosario et al. 2008, Soares et al. 2012). However, there are few studies that have evaluated the effects of endocrine disorders on the placental immunology and on the migration of trophoblast cells, particularly in hypo- and hyperthyroidism.

Thyroid hypofunction affects fetal-placental development, impairing the decidualization, vascularization, and development of the placenta, increasing apoptosis, and reducing the proliferation of trophoblast cells (Shafrir et al. 1994, Morrish et al. 1997, Galton et al. 2001, Silva et al. 2012). However, several of the pathological processes observed in hypothyroidism may result from changes in the placental pro- and anti-inflammatory cytokine profile (Koga et al. 2009). In contrast, hyperthyroidism increases reproductive efficiency in experimental animal models (Serakides et al. 2001, Freitas et al. 2007) and causes significant changes in the uterine vasculature (Souza et al. 2011) and in the proliferation of trophoblast cells (Freitas et al. 2007). It is important to mention that placental changes similar to those observed in hypo- and hyperthyroidism may also be influenced by the migration kinetics of the trophoblast cells (Knöfler 2010, Hammer 2011, Chakraborty et al. 2011, Soares et al. 2012). 
The maternal immune system is suppressed during pregnancy. A significant reduction in cellular immunity (Weinberg 1987, Raghupathy 1997) and predominance of anti-inflammatory cytokines, such as interleukin 4 (IL4), IL10, and inducible nitric oxide synthase (NOS2 (iNOS)), are essential conditions for the success of pregnancy (Coulam 2000, Toder et al. 2003). This is crucial to prevent rejection of the fetus (Murphy et al. 2004). However, while immune system suppression is essential during pregnancy, it increases susceptibility to various infectious agents (Kim et al. 2005).

Bacterial antigen recognition by trophoblast cells is mediated by multiple membrane receptors, especially Toll-like receptors (TLRs; Flo et al. 2002). Stimulation of TLR2 and TLR4 results in apoptosis and production of inflammatory cytokines by trophoblast cells respectively (Koga et al. 2009). However, little is known about the influence of thyroid dysfunction on the expression of these receptors. It has been observed that TLRs are associated with pregnancy complications, such as pathogenesis of pre-eclampsia, preterm delivery, and even the failure of fetal development (Koga \& Mor 2010, Xie et al. 2010). Some pro-inflammatory cytokines, such as interferon $\gamma$ (INFy) and the macrophage migration inhibitory factor (MIF), are also important components of the placental immune response. INFy stimulates the phagocytic activity of macrophages and trophoblast giant cells against microorganisms (Ashkar et al. 2000, Kim et al. 2005). MIF stimulates the expression of a wide variety of proinflammatory cytokines, such as tumor necrosis factor (TNF (TNF $\alpha$ )), INFy, IL2, IL6, and IL8 (Faria et al. 2010, Cardaropoli et al. 2012), stimulates angiogenesis and cell proliferation, and suppresses apoptosis (Amin et al. 2003, Viganò et al. 2007, Faria et al. 2010, Cardaropoli et al. 2012). One hypothesis is that the expression of TLRs and inflammatory cytokines in trophoblast cells are impaired in hypothyroidism. This would compromise the fetalplacental development not only by influencing the permanence of the fetus in the uterine environment but also by facilitating infection by pathogens.

Inflammatory cytokines may also influence the invasion of trophoblast cells toward the decidua through its effects on the extracellular matrix remodeling and on the vascular compartment of the mesometrial decidua (Cartwright et al. 1999, Ain et al. 2003). Cartwright et al. (1999) demonstrated that the motility and invasion of the trophoblast cells is highly dependent on the NOS produced by trophoblasts in vitro. Silva et al. (2012) observed changes in the glycogen cell population as well as in trophoblast giant cells in the placentas of rats with hypothyroidism, suggesting that there is a failure in the migration kinetics of these cells toward the decidua.

Invasive trophoblasts fulfill numerous functions including anchoring the placenta to the maternal tissue, hormone secretion, modulation of decidual angiogenesis and lymphangiogenesis, and remodeling of maternal uterine spiral arteries (Knöfler 2010,
Chakraborty et al. 2011). Research has shown that several growth factors, angiogenic, cytokines, and proteases control the trophoblastic cell migration kinetics (Soares et al. 2012). Among these factors are the matrix metalloproteinase 2 (MMP2) and MMP9, and placental leptin (Knöfler 2010, Soares et al. 2012). However, the influence of these factors on the dynamics of trophoblast cells in the maternal-fetal interface remains poorly understood and requires further studies (Ain et al. 2003). The failure of the migration kinetics of trophoblast cells in humans or model organisms with hypothyroidism also remains unproven, as does the participation of MMPs and placental leptin in this process in vivo.

Based on these previous findings and hypotheses, the objective of the work presented was to study the placental gene expression of TLRs, the immunohistochemical and gene expression of pro- and anti-inflammatory cytokines, and the migration kinetics of trophoblast cells in animals with induced thyroid dysfunction.

\section{Materials and methods}

All experimental procedures were approved by the Institutional Ethics Committee in Animal Experimentation at the Universidade Federal de Minas Gerais (protocol no. 239/2009).

\section{Induction of thyroid dysfunction and mating}

A total of 144 adult female Wistar rats were used in this study. Rats were housed in cages with six rats per cage in a $12 \mathrm{~h}$ light: $12 \mathrm{~h}$ darkness cycle. They were fed with commercial rat chow containing $22 \%$ crude protein, $1.4 \%$ calcium, and $0.6 \%$ phosphorus. Food and water were provided ad libitum.

After a 7-day adaptation period, the rats were randomly divided into three groups (control, hypothyroid, and thyroxine $\left(\mathrm{T}_{4}\right.$ )-treated) with 48 rats per group.

Hypothyroidism was induced by administration of propylthiouracil (PTU) diluted in $5 \mathrm{ml}$ distilled water, in accordance with the method of Silva et al. (2004), using an orogastric probe ( $1 \mathrm{mg} /$ animal per day). The $\mathrm{T}_{4}$-treated rats received $\mathrm{L} \mathrm{T}_{4}$ diluted in $5 \mathrm{ml}$ distilled water, as described by Serakides et al. (2001), using an orogastric probe $(50 \mu \mathrm{g} / \mathrm{animal}$ per day). The rats from the control group received $5 \mathrm{ml}$ distilled water/day as a placebo.

Five days after treatment initiation, female rats from all groups were subjected to vaginal cytology to monitor the estrous cycle. Six rats from each group were also killed with an overdose of anesthetic for blood collection, measurement of free $\mathrm{T}_{4}$, and confirmation of the induction of thyroid dysfunction. The rats in proestrus were kept in plastic cages with adult male rats for $12 \mathrm{~h}$ during the night. After this period, vaginal smears were obtained on the next morning to detect spermatozoa. Copulation was confirmed by the presence of spermatozoa in vaginal cytology and that day was considered to be day 0 of gestation. After copulation, the female rats were kept individually in plastic cages. Rats in the hypothyroid, $\mathrm{T}_{4}$-treated, and control groups continued to receive PTU, $\mathrm{T}_{4}$, and water, respectively, by an orogastric probe throughout the experimental period. 


\section{Hormone analysis}

At $0,10,14,15,16,17,18$, and 19 days of gestation, six rats from each group were killed by an overdose of anesthetic $(2.5 \%$ Tionembutal; Abbott). At 0 and 19 days of gestation, blood was collected from the rats and serum was separated by centrifugation and stored at $-20{ }^{\circ} \mathrm{C}$ for the measurement of free $T_{3}$ and $T_{4}$, which was performed using the chemiluminescence ELISA technique with commercial kits and in accordance with the manufacturer's instructions (IMMULITE, Siemens Medical Solutions Diagnostics, Malvern, PA, USA). The intra- and interassay coefficients of variation were 4 and $7 \%$ respectively.

\section{Necropsy and material collection}

At necropsy, the uterus was collected together with the placenta and fetuses. Six placental disks along with the decidua and metrial gland per rat were fixed in $4 \%$ paraformaldehyde for $20 \mathrm{~h}$ and were processed using a routine paraffin inclusion technique. To perform immunohistochemistry and morphological measurements, histological sections $(4 \mu \mathrm{m})$ of placental disks along with the decidua and metrial gland were obtained and placed on silanized slides.

Three placental disks without decidua and metrial gland per rat were also dissected, snap frozen in liquid nitrogen, and stored at $-80{ }^{\circ} \mathrm{C}$ for use in the evaluation of the gene expression of T/r2 and TIr4, Infy, Mif, Tnf, II10, Nos2, Mmp2 and Mmp9, and placental leptin using real-time RT-PCR. Placental disks were formed only by syncytiotrophoblast, spongiotrophoblast, and placental labyrinth.

\section{Immunohistochemistry and morphological measurements}

The biotin-streptavidin-peroxidase (Streptavidin Peroxidase, Lab Vision Corp., Fremont, CA, USA) technique was used for immunohistochemistry. Antigenic recovery using a retrieval solution was performed for $20 \mathrm{~min}$. Histological sections were incubated overnight in a humidified chamber with the primary antibody. The primary antibodies and their dilutions included anti-cytokeratin AE1/AE3 (Clone AE1-AE3, Dako, St Louis, MO, USA; 1:100), anti-INFy (AB9657, Abcam, Cambridge, UK; 1:200), anti-MIF (AB7207, Abcam; 1:500), and anti-iNOS (AB15323, Abcam; 1:100). The sections were incubated stepwise for $30 \mathrm{~min}$ with each of the following solutions: blocking endogenous peroxidase, blocking serum (Ultra Vision Block, Lab Vision Corp.), and streptavidin peroxidase. Incubation with the secondary antibody (goat biotin, Lab Vision Corp.) was performed for $45 \mathrm{~min}$. The chromogen diaminobenzidine (DAB substrate system, Lab Vision Corp.) was used for visualization. Sections were counterstained with Harris hematoxylin. A negative control was included by replacing the primary antibodies with IgG.

Rat invasive trophoblast cells were detected using the anticytokeratin AE1/AE3 antibody. The depth of intrauterine endovascular and interstitial trophoblast cell invasion was used to determine an invasion index according to Rosario et al. (2008). The endovascular trophoblast invasion was evaluated by measuring the distance of endovascular cytokeratin-positive cell location relative to the trophoblast giant cell layer of the chorioallantoic placenta/total distance from the trophoblast giant cell layer to the outer mesometrial surface of the uterus. The interstitial trophoblast invasion was measured by the distance of interstitial cytokeratin-positive cell location relative to the trophoblast giant cell layer of the chorioallantoic placenta/ total distance from the trophoblast giant cell layer to the outer mesometrial surface of the uterus. The depth of intrauterine trophoblast cell invasion was evaluated from a histological plane at the center of each placentation site perpendicular to the flat fetal surface of the placenta. Sample sizes for the analyses were at least five placentation sites from at least five different animals per treatment group. All analyses were performed on placental disks at 14, 15, 16, 17, and 18 days of gestation.

The immunostaining intensity and stained area of INFy, MIF, and NOS2 in the spongiotrophoblast layer and placental labyrinth were evaluated at 14 and 19 days of gestation. To determine the immunostaining intensity and stained area, images from six and eight random fields per each layer at 14 and 19 days of gestation, respectively, were photographed with an Olympus BX-40 microscope and the Spot Color Insight digital camera (SPOTTM, Sterling Heights, MI, USA), and the immunostaining intensity and stained area were determined using WCIF ImageJ Software (Media Cybernetics Manufacturing, Rockville, MD, USA). Color deconvolution and thresholding of the images were performed. To ensure the objectivity of the procedure, the mean was obtained from the evaluation of three placental disks per animal. Data from each placental disk were archived, analyzed, and expressed as the integrated density and stained area in pixels.

\section{Real-time RT-PCR}

Total mRNA from placental disks was extracted using TRIzol reagent (Invitrogen) according to the manufacturer's instructions. A total of $1 \mu \mathrm{g}$ RNA was used for cDNA synthesis using the SuperScript III Platinum Two-Step qPCR Kit with SYBR Green (Invitrogen). The qRT-PCRs were conducted in a Smart Cycler II thermocycler (Cepheid, Inc., Sunnyvale, CA, USA). To quantify the cDNA generated by RT, real-time PCR with SYBR Green I was performed using SYBR Green PCR Master Mix in an Applied Biosystems 7500 Real-Time PCR System (Applied Biosystems, Life Technologies). For negative controls, we used a complete DNA amplification mix in which the target cDNA template was replaced with water. Amplifications were performed using the default cycling conditions: enzyme activation at $95^{\circ} \mathrm{C}$ for $10 \mathrm{~min}, 40$ cycles of denaturation at $95^{\circ} \mathrm{C}$ for $15 \mathrm{~s}$, and annealing/extension at $60{ }^{\circ} \mathrm{C}$ for $60 \mathrm{~s}$. To assess the linearity and efficiency of PCR amplification, standard curves for all transcripts were generated using serial dilutions of cDNA. A melting curve was obtained for the amplification products to ascertain their melting temperatures. The samples were assayed in triplicate and then a gel was run with the reaction product to confirm the gene amplification. The PCR products were separated by electrophoresis on $1 \%$ agarose gels and stained with ethidium bromide. Gene expression was calculated using the $2^{-\Delta \Delta C T}$ method, where the values from the samples were averaged and calibrated in relation to $\beta$-actin $C T$ values. The primers were as follows (Table 1). 
Table 1 List of genes with primer sequences.

\begin{tabular}{|c|c|c|}
\hline Gene & Primer sequences & Accession number \\
\hline \multirow[t]{2}{*}{ Tlr2 } & Forward, 5'-CTGGAGAGGCCAGCССТGGT-3' & NM_198769.2 \\
\hline & Reverse, 5'-CTCTGGCCATGCAGGCGAGG-3' & \\
\hline \multirow[t]{2}{*}{ Tlr4 } & Forward, 5'-GGGGCAACCGCTGGGAGAGA-3' & NM_019178.1 \\
\hline & Reverse, 5'-AACCAGCGGAGGCCGTGAGA-3' & \\
\hline \multirow[t]{2}{*}{ Infy } & Forward, 5'-AGTGCTACACGCCGCGTCTT-3' & NM_138880.2 \\
\hline & Reverse, 5'-AGTGTGCCTTGGCAGTAACAGCC-3' & \\
\hline \multirow[t]{2}{*}{ Mif } & Forward, 5'-AACACCGTCCTCCGGCCGTC-3' & NM_031051.1 \\
\hline & Reverse, 5'-GGCGCGGGGAACATTGGTGT-3' & \\
\hline \multirow[t]{2}{*}{ Tnf } & Forward, 5'-AGCCCGTAGCCCACGTCGTA-3' & NM_012675.3 \\
\hline & Reverse, 5'-CGGTGTGGGTGAGGAGCACG-3' & \\
\hline \multirow[t]{2}{*}{$1 / 10$} & Forward, 5'-GGCCATTCCATCCGGGGTGA-3' & NM_012854.2 \\
\hline & Reverse, 5'-AAGGCAGCССТCAGCTCTCG-3' & \\
\hline \multirow[t]{2}{*}{ Nos2 } & Forward, 5'-TGGTCCTGCAGGCTCACGGT-3' & NM_012611.3 \\
\hline & Reverse, 5'-ACTCGAGGCCACCСАССТCС-3' & \\
\hline \multirow[t]{2}{*}{ Mmp2 } & Forward, 5'-TGGGCССТССССТGATGCTG-3' & NM_031054.2 \\
\hline & Reverse, 5'-AGCAGCCCAGCCAGTCCGAT-3' & \\
\hline \multirow[t]{2}{*}{ Mmp9 } & Forward, 5'-TGCACCACCTTACCGGCCCT-3' & NM_031055.1 \\
\hline & Reverse, 5'-CAGCGCCCGACGCACAGTAA-3' & \\
\hline \multirow[t]{2}{*}{ Placental leptin } & Forward, 5'-CTGGAGACСССТGTGCCGGT-3' & NM_013076.3 \\
\hline & Reverse, 5'-GCCTGGCGGATACCGACTGC-3' & \\
\hline \multirow[t]{2}{*}{$\beta$-actin } & Forward, 5'-TCCACCCGCGAGTACAACCTTCTT-3' & NM_031144.2 \\
\hline & Reverse, 5'-CGACGAGCGCAGCGATATCGT-3' & \\
\hline
\end{tabular}

The evaluation of the gene expression of the inflammatory mediators was performed at 10,14, and 19 days of gestation. The evaluation of the gene expression of Mmp2 and Mmp9 and placental leptin was performed at 10, 14, and 18 days of gestation.

\section{Statistical analysis}

Significant differences in the mean values between the experimental groups were determined by one-way ANOVA. The Student-Newman-Keuls test was used to compare data between groups, and the differences were considered to be significant if $P<0.05$.

\section{Results}

\section{Induction of thyroid dysfunction}

Hypothyroidism and excess of $\mathrm{T}_{4}$ during the entire period of the pregnancy was confirmed by assaying the free $T_{3}$ and $T_{4}$ levels in serum on days 0 and 19 of gestation and by the evaluation of symptoms. The rats treated with PTU displayed free $\mathrm{T}_{3}$ and $\mathrm{T}_{4}$ levels lower than those of the control group $(P<0.05$; Fig. 1$)$ and clinical characteristics of lethargy. The $\mathrm{T}_{4}$-treated rats exhibited higher free $\mathrm{T}_{4}$ levels compared with control rats $(P<0.05$; Fig. 1$)$ and showed clinical characteristics of aggressiveness.

\section{Immunohistochemical expression of INFy, MIF, and NOS2}

Regardless of the experimental group, the placenta showed expression of INFy, MIF, and NOS2 in three layers (syncytiotrophoblast, spongiotrophoblast, and placental labyrinth), at 14 and 19 days of gestation. The immunohistochemical expression of INFy and MIF was nuclear and/or cytoplasmic, unlike the NOS2 expression that was only cytoplasmic, with a more intense expression at 14 days of gestation compared with 19 days of gestation (Figs 2, 3 and 4).

Hypothyroidism reduced the area and intensity of INFy immunohistochemical expression at 14 and 19 days of gestation in the spongiotrophoblast layer
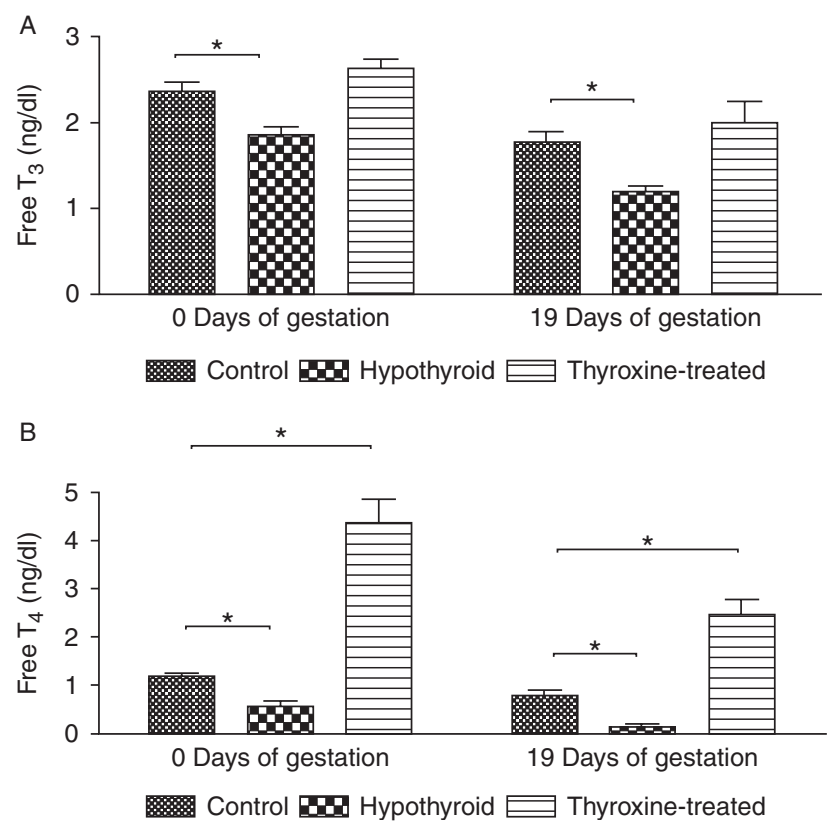

Figure $1(A$ and $B)$ Free $T_{3}$ and $T_{4}$ levels (mean \pm s.D.) in the plasma of pregnant rats from the control, hypothyroid, and thyroxine-treated groups at 0 and 19 days of gestation $\left({ }^{*} P<0.05\right)$. 

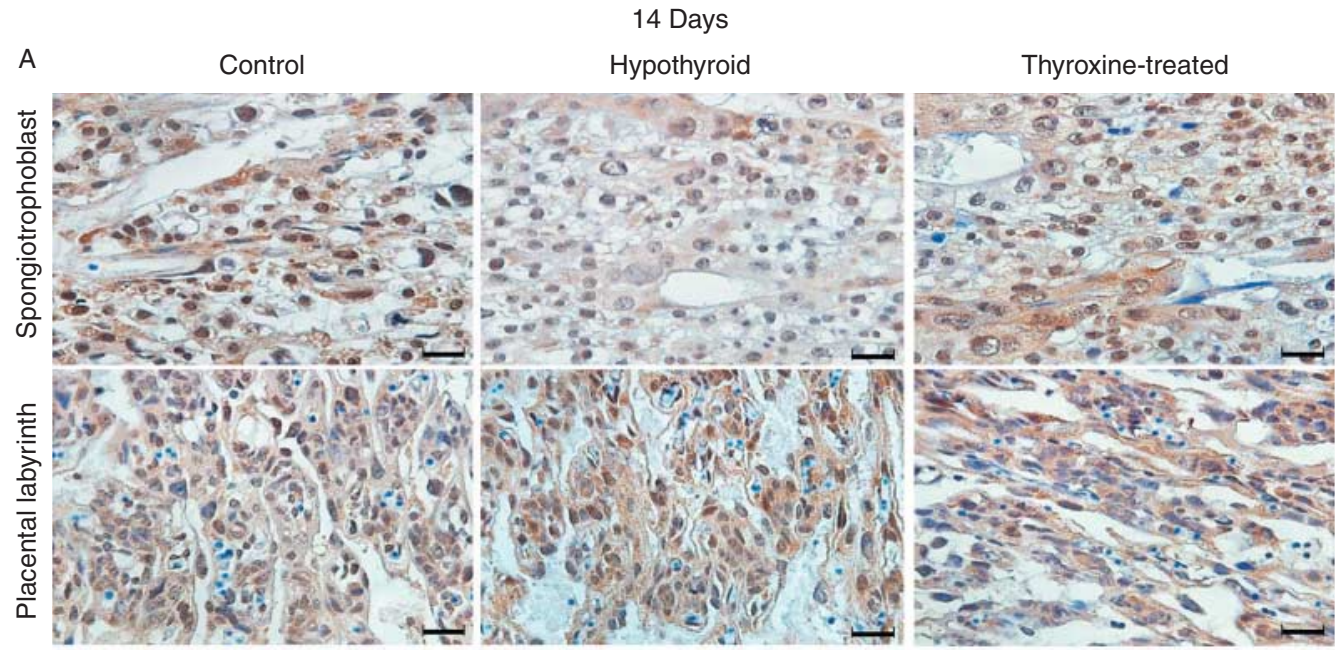

19 Days

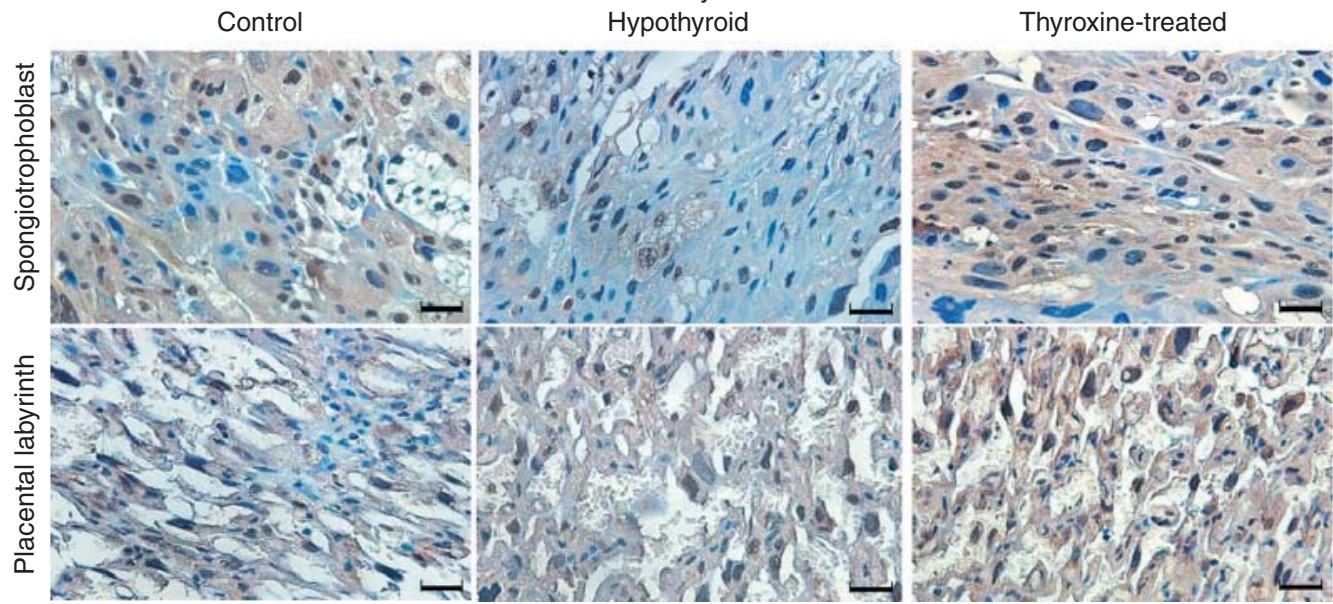

B

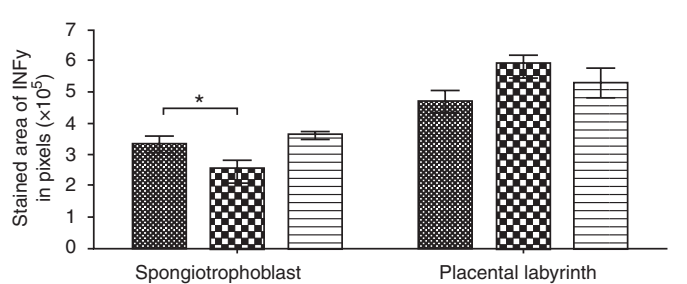

14 Days

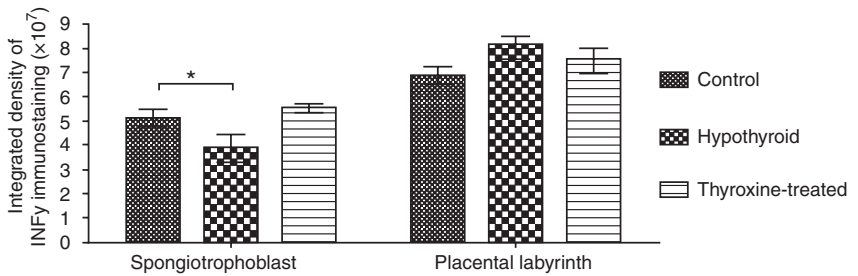

C

19 Days

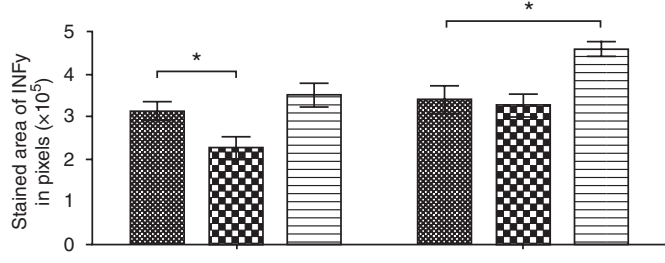

Spongiotrophoblast

Placental labyrinth
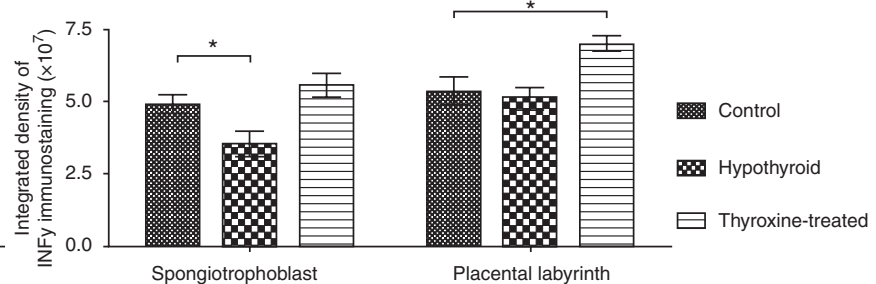

Spongiotrophoblast

Placental labyrinth

Figure 2 INFy expression in the placenta of pregnant rats from the control, hypothyroid, and thyroxine $\left(\mathrm{T}_{4}\right)$-treated groups at 14 and 19 days of gestation. (A) Immunohistochemical images of INFy expression (streptavidin-biotin-peroxidase, Harris hematoxylin, scale bar=12 $\mu \mathrm{m})$. (B and C) Reduction in the area and intensity of INFy expression in the spongiotrophoblast layer of the hypothyroid group compared with the control group at 14 and 19 days of gestation. Increase in the area and intensity of INFy expression in the placental labyrinth of $\mathrm{T}_{4}$-treated group compared with the control group at 19 days of gestation $\left({ }^{*} P<0.05\right)$. 


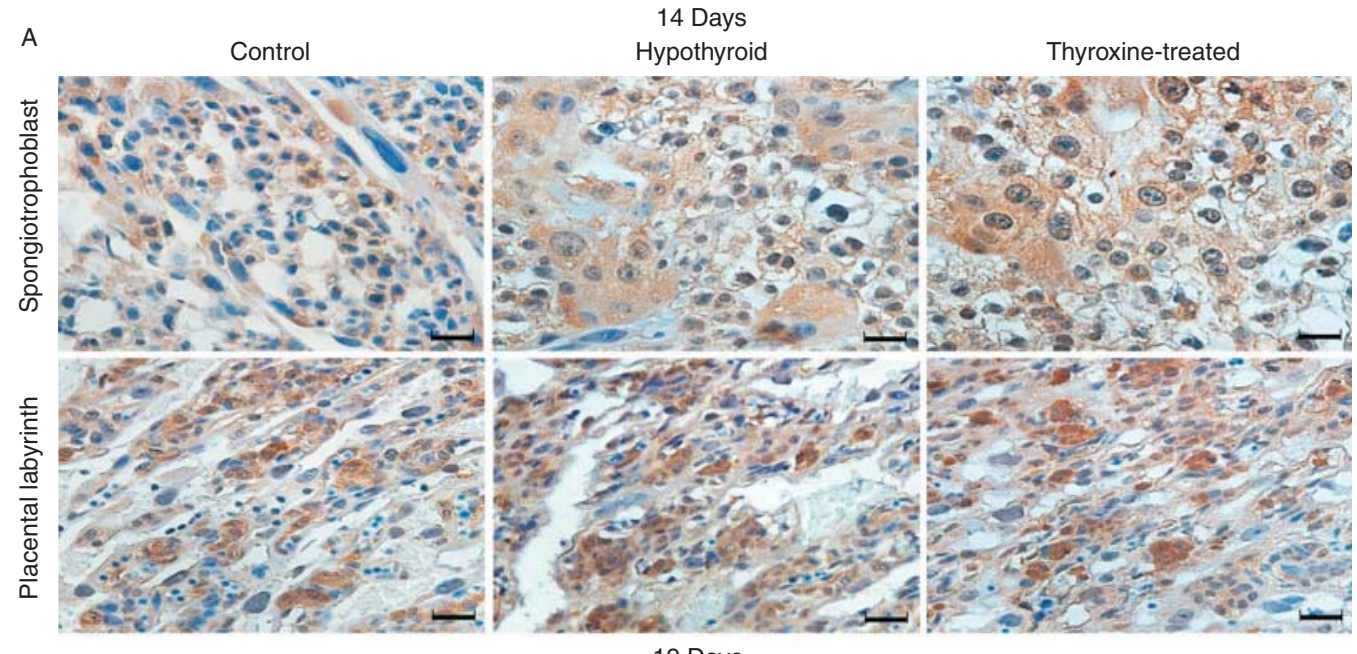

19 Days

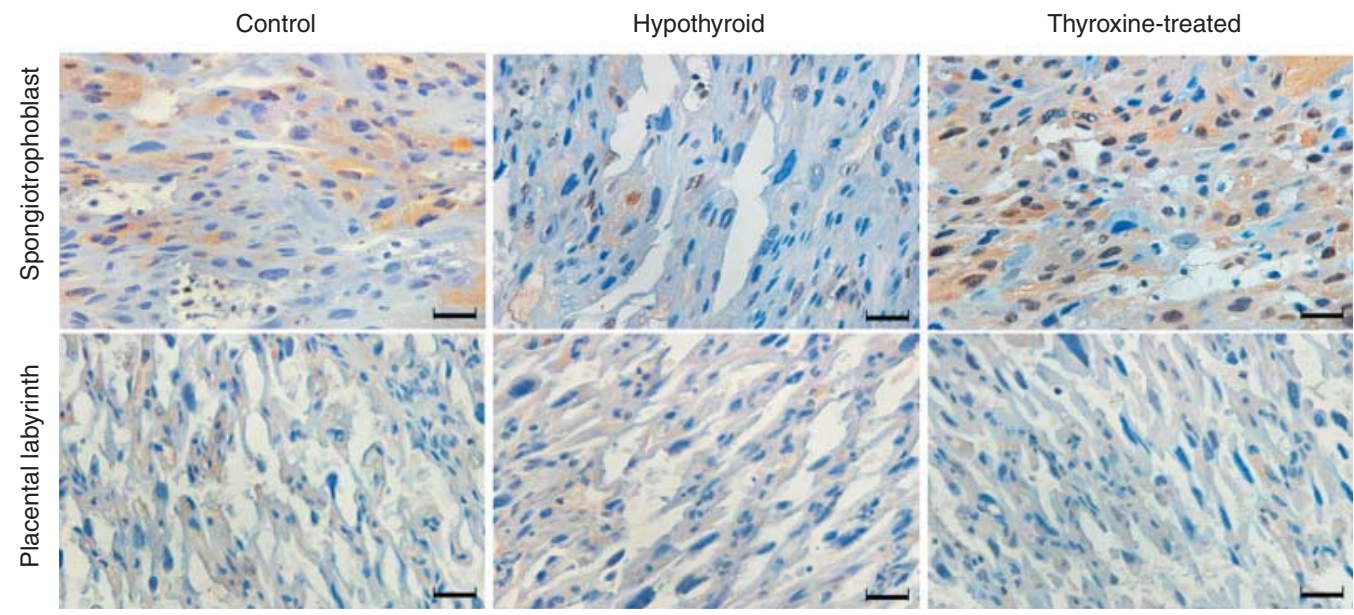

B

14 Days
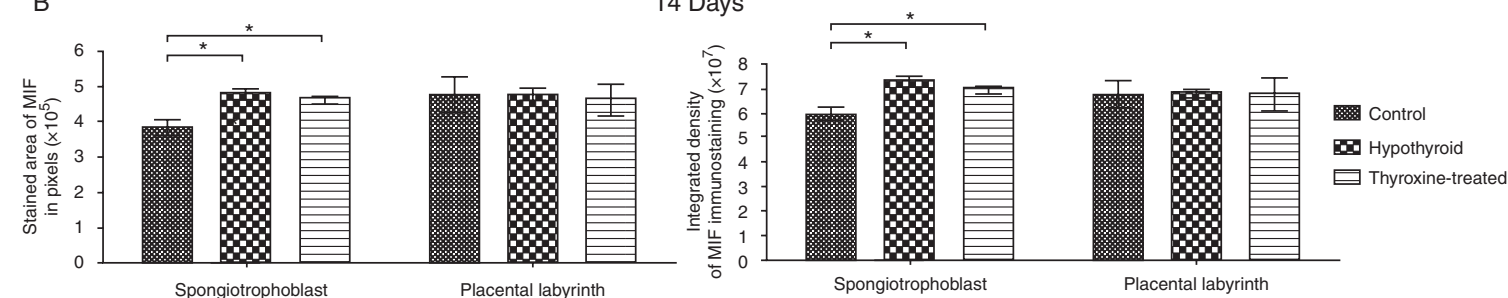

C

19 Days
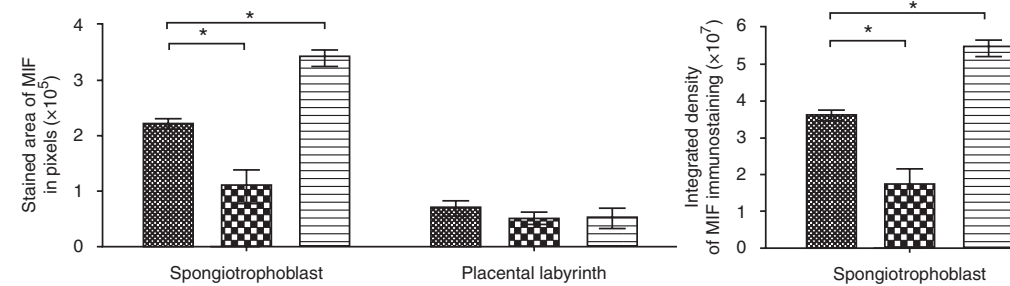

ॠ Control

Hypothyroid

$\square$ Thyroxine-treated

Figure $3 \mathrm{MIF}$ expression in the placenta of pregnant rats from the control, hypothyroid, and thyroxine $\left(\mathrm{T}_{4}\right)$-treated groups at 14 and 19 days of gestation. (A) Immunohistochemical images of MIF expression (streptavidin-biotin-peroxidase, Harris hematoxylin, scale bar $=12 \mu \mathrm{m})$. (B and C) Increase in the area and intensity of MIF expression in the spongiotrophoblast layer of the hypothyroid and $\mathrm{T}_{4}$-treated group compared with the control group at 14 days of gestation. Reduction in the hypothyroid group and increase in the $\mathrm{T}_{4}$-treated group with regard to the area and intensity of MIF expression in the spongiotrophoblast layer compared with the control group at 19 days of gestation $\left({ }^{*} P<0.05\right)$. 
A

14 Days

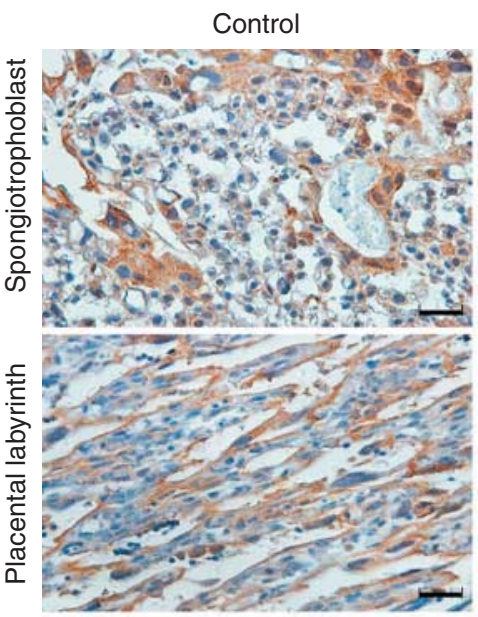

Hypothyroid

Thyroxine-treated
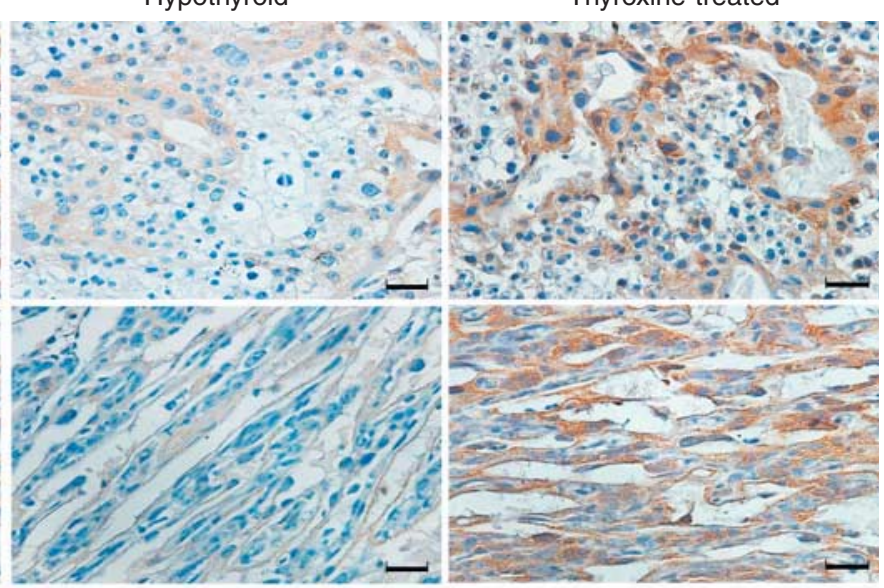

19 Days

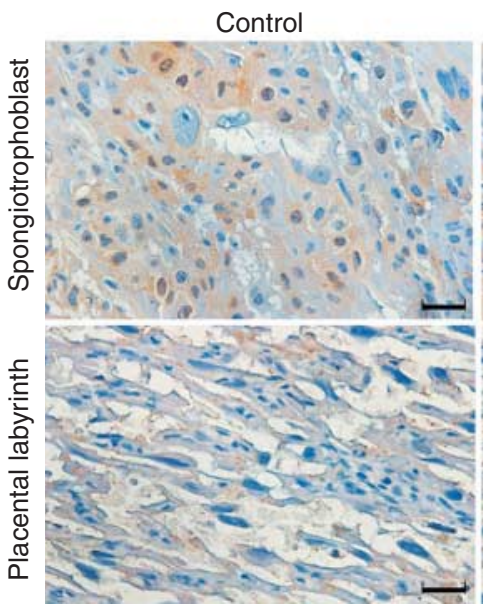

Hypothyroid

Thyroxine-treated
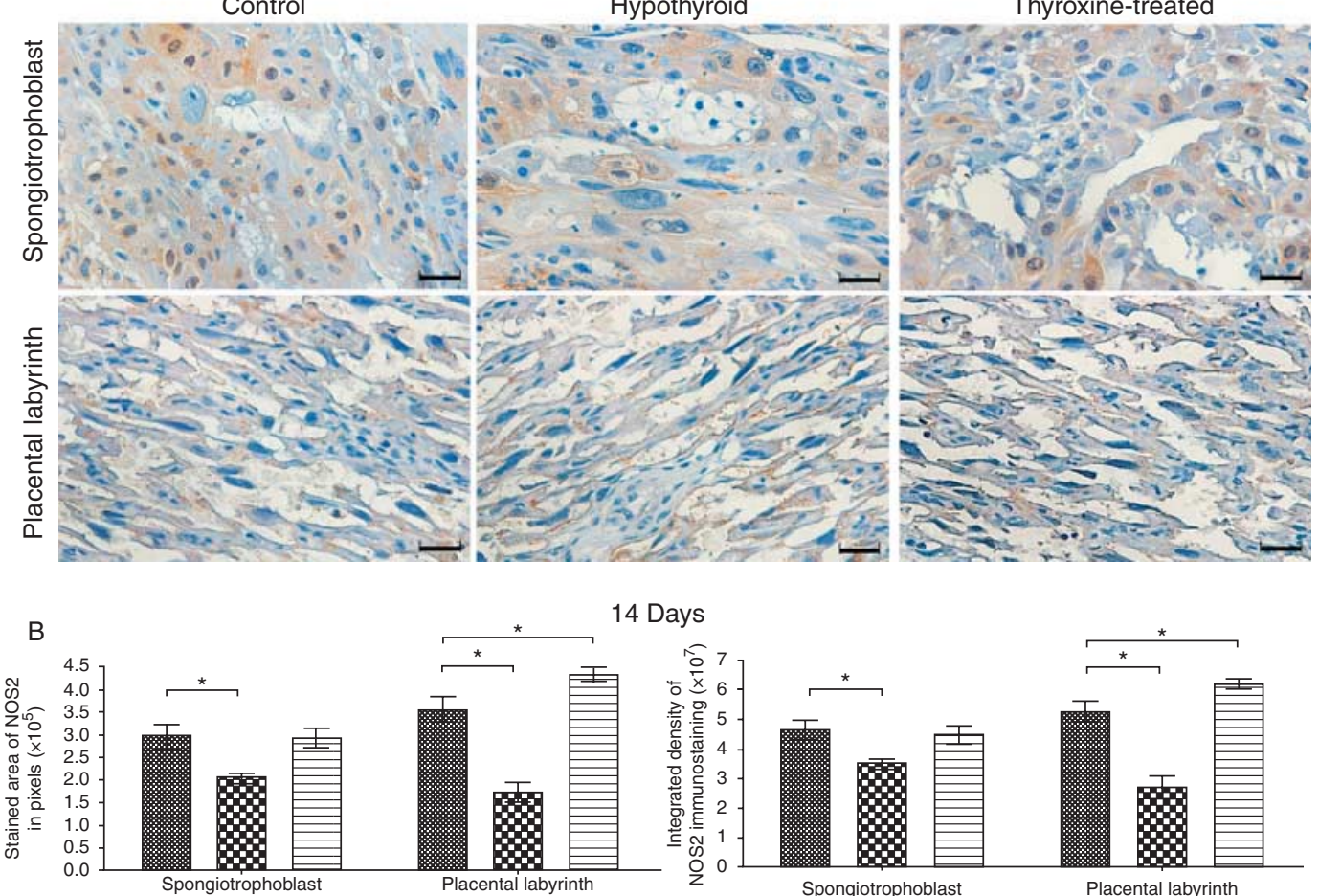

14 Days

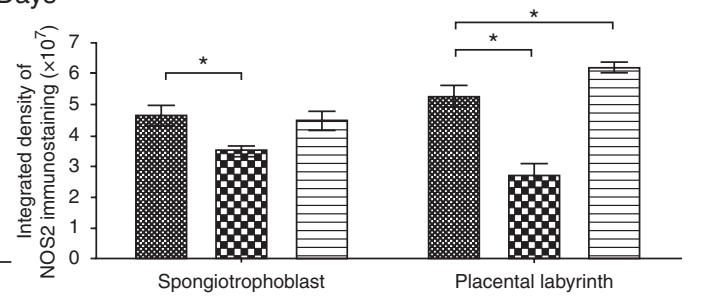

ख Control

00 Hypothyroid

$\Xi$ Thyroxine-treated

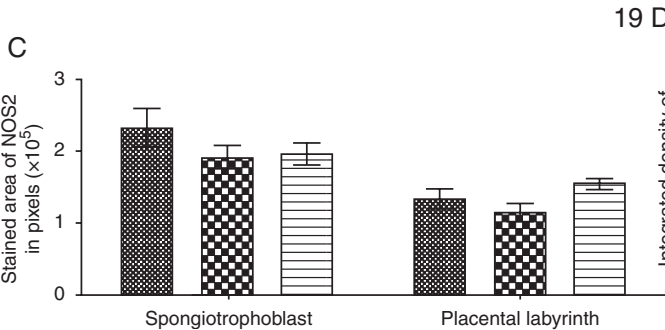

9 Days

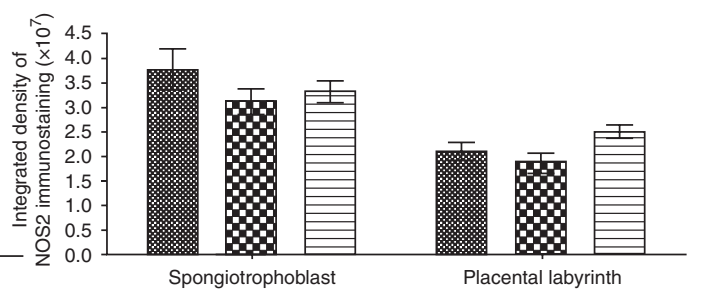

제 Control

Hypothyroid

曰Thyroxine-treated

Figure 4 NOS2 expression in the placenta of pregnant rats from the control, hypothyroid, and thyroxine $\left(\mathrm{T}_{4}\right)$-treated groups at 14 and 19 days of gestation. (A) Immunohistochemical images of NOS2 expression (streptavidin-biotin-peroxidase, Harris hematoxylin, scale bar $=12 \mu \mathrm{m}$ ). (B and C) Reduction in the area and intensity of NOS2 expression in the spongiotrophoblast layer and placental labyrinth of the hypothyroid group compared with the control group at 14 days of gestation. Increase in the area and intensity of NOS2 expression in the placental labyrinth of the $\mathrm{T}_{4}$-treated group compared with the control group at 14 days of gestation $\left({ }^{*} P<0.05\right)$. 
when compared with the control rats $(P<0.05$; Fig. 2$)$. This was different from the $\mathrm{T}_{4}$-treated rats, which exhibited an increase in the area and intensity of INFy immunohistochemical expression in the placental labyrinth at 19 days of gestation when compared with the control group $(P<0.05$; Fig. 2$)$.

In relation to the MIF expression, the hypothyroid group showed an increase in the area and intensity of immunohistochemical expression in the spongiotrophoblast layer compared with the control group at 14 days of gestation, but this was not observed at 19 days of gestation. Instead of that, at 19 days of gestation, a reduction in the area and intensity of MIF immunohistochemical expression in the spongiotrophoblast layer was observed in the hypothyroid rats compared with the control rats $(P<0.05 ;$ Fig. 3$)$. $\mathrm{T}_{4}$-treated rats showed an increase in the area and intensity of immunohistochemical expression of MIF in the spongiotrophoblast layer at 14 and 19 days of gestation compared with the control rats $(P<0.05 ;$ Fig. 3$)$. In placental labyrinth, at 14 and 19 days of gestation, there was no difference on the MIF immunohistochemical expression between the groups (P>0.05; Fig. 3).

At 14 days of gestation, the hypothyroid animals showed a reduction in the area and intensity of NOS2 immunohistochemical expression in the spongiotrophoblast layer and placental labyrinth compared with the control group $\left(P<0.05\right.$; Fig. 4). The $\mathrm{T}_{4}$-treated rats, differing from the hypothyroid group, showed an increase in the area and intensity of immunohistochemical expression of NOS2 in the placental labyrinth at 14 days of gestation compared with the control rats $(P<0.05$; Fig. 4$)$.

\section{Gene expression of TLR2 and TLR4}

At 14 days of gestation, the placental disks of hypothyroid rats showed an increased expression of
mRNA for T/r2 compared with the control rats $(P<0.05)$. The $\mathrm{T}_{4}$-treated group showed no differences in gene expression of Tlr2 compared with the control group in any of the gestational periods ( $P>0.05$; Fig. $5 \mathrm{~A})$.

The hypothyroid group had decreased TIr4 mRNA expression at 10,14, and 19 days of gestation compared with the control rats $(P<0.05$; Fig. $5 \mathrm{~B})$. The $\mathrm{T}_{4}$-treated group showed no differences in T/r4 gene expression compared with the control group in any of the gestational periods ( $P>0.05$; Fig. $5 \mathrm{~B})$.

\section{Gene expression of the pro-inflammatory cytokines Infy, Mif, and Tnf}

Hypothyroid rats showed reduced expression of mRNA for Infy at 10 and 14 days of gestation compared with the control rats $(P<0.05)$. This was different from the $\mathrm{T}_{4}$-treated rats, which exhibited increased Infy gene expression compared with the control group at 19 days of gestation $(P<0.05$; Fig. $6 \mathrm{~A})$.

In contrast to the expression of INFy, the hypothyroid rats showed no differences in gene expression of Mif in relation to the control rats at any of the gestational time points $(P>0.05 ;$ Fig. $6 \mathrm{~B})$. The $\mathrm{T}_{4}$-treated group showed a decrease in the mRNA expression of Mif compared with the control group at as early as 10 days of gestation, but this was not observed at 19 days of gestation. At 19 days of gestation, an increase in Mif gene expression was observed in the $\mathrm{T}_{4}$-treated rats compared with the control rats $(P<0.05$; Fig. $6 \mathrm{~B})$.

Regarding Tnf gene expression, the hypothyroid rats showed no differences compared with the control rats at any of the gestational time points $(P>0.05)$, as opposed to the $\mathrm{T}_{4}$-treated rats, which showed a decrease in mRNA expression of Tnf compared with the control group at 10 days of gestation $(P<0.05)$ (Fig. 6C). At 14 and 19 days of gestation, there were no differences in gene
A

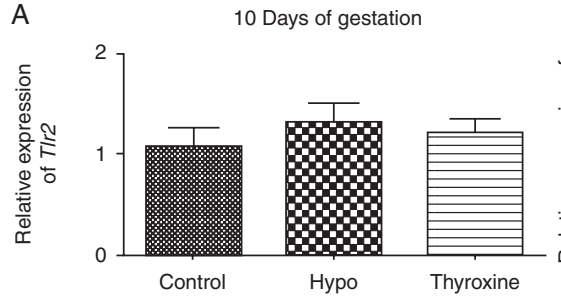

B

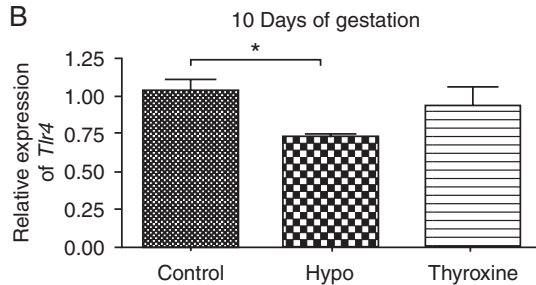

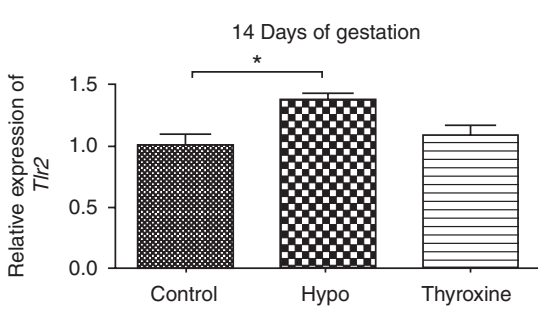

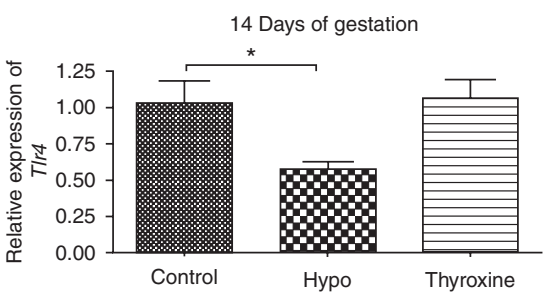

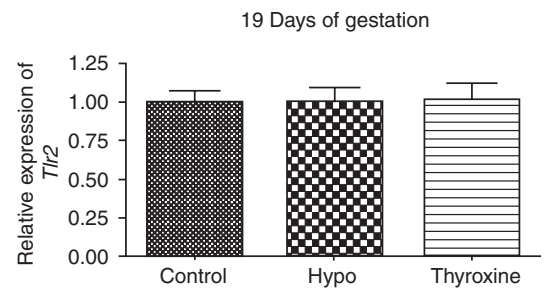

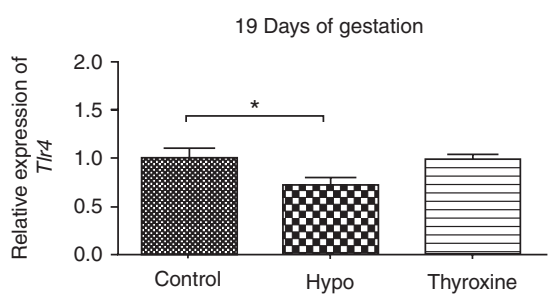

Figure 5 Relative expression of gene transcripts for T/r2 (A) and Tlr4 (B) (mean \pm s.D.) in the placentas of pregnant rats from the control, hypothyroid, and thyroxine-treated groups at 10,14 , and 19 days of gestation $\left({ }^{*} P<0.05\right)$. 
A

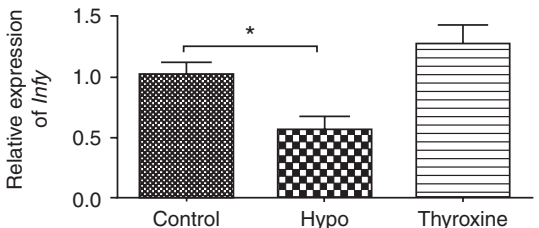

B

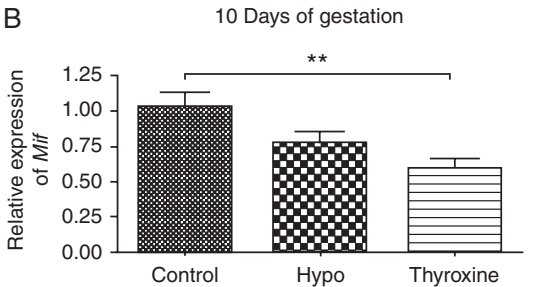

C

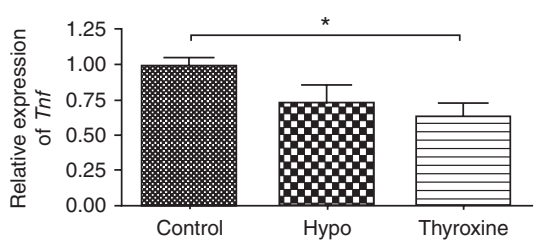

14 Days of gestation

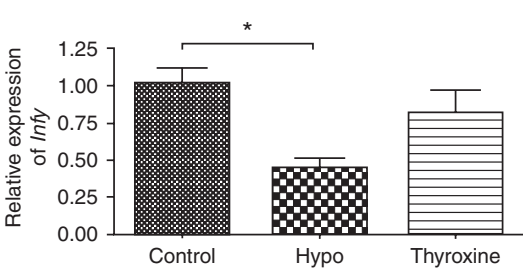

14 Days of gestation

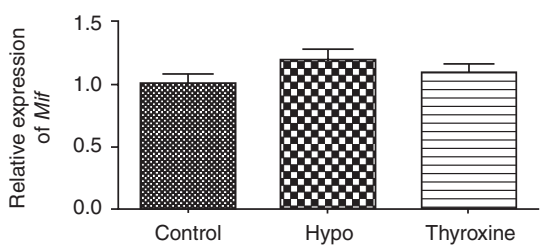

14 Days of gestation

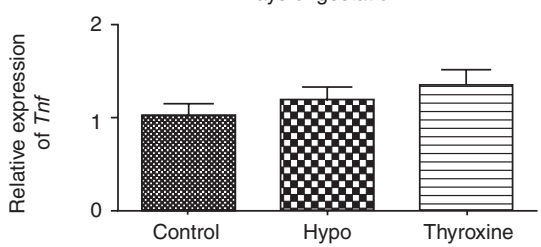

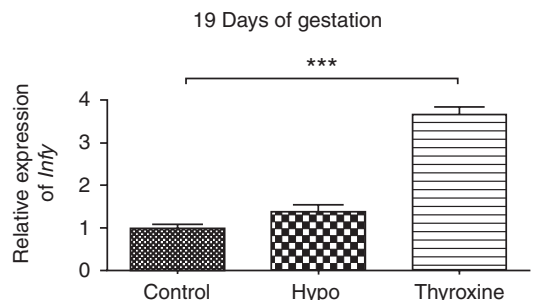

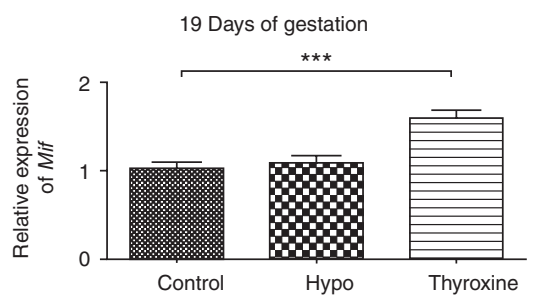

19 Days of gestation

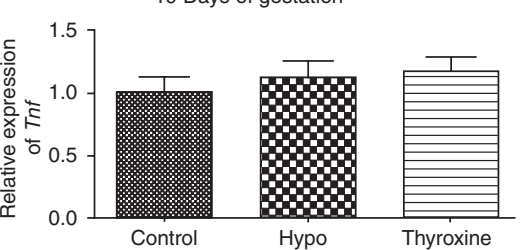

Figure 6 Relative expression of gene transcripts for $\operatorname{Infy}(\mathrm{A}), \operatorname{Mif}(\mathrm{B})$, and $\operatorname{Tnf}(\mathrm{C})$ (mean \pm s.D.) in the placentas of pregnant rats from the control, hypothyroid, and thyroxine-treated groups at 10,14 , and 19 days of gestation $\left({ }^{*} P<0.05\right.$, ${ }^{* *} P<0.01$, and $\left.{ }^{* * *} P<0.001\right)$.

expression of $T n f$ between the $\mathrm{T}_{4}$-treated and control groups $(P>0.05$; Fig. 6C).

\section{Gene expression of the anti-inflammatory cytokines Il10 and Nos2}

Hypothyroid rats showed a decrease in $1 / 10$ gene expression at 14 days of gestation compared with the control rats $(P<0.05$; Fig. $7 \mathrm{~A}) . \mathrm{T}_{4}$-treated rats, in contrast, showed an increase in gene expression of $/ / 10$ compared with the control rats at 10 and 19 days of gestation $(P<0.05$; Fig. 7A).

Hypothyroid rats also showed a reduction in Nos2 mRNA expression compared with the control rats at 14 days of gestation ( $P>0.05$; Fig. $7 \mathrm{~B})$. The $\mathrm{T}_{4}$-treated group showed no differences in Nos2 gene expression when compared with the control group at any of the gestational ages tested ( $P>0.05$; Fig. $7 \mathrm{~B})$.
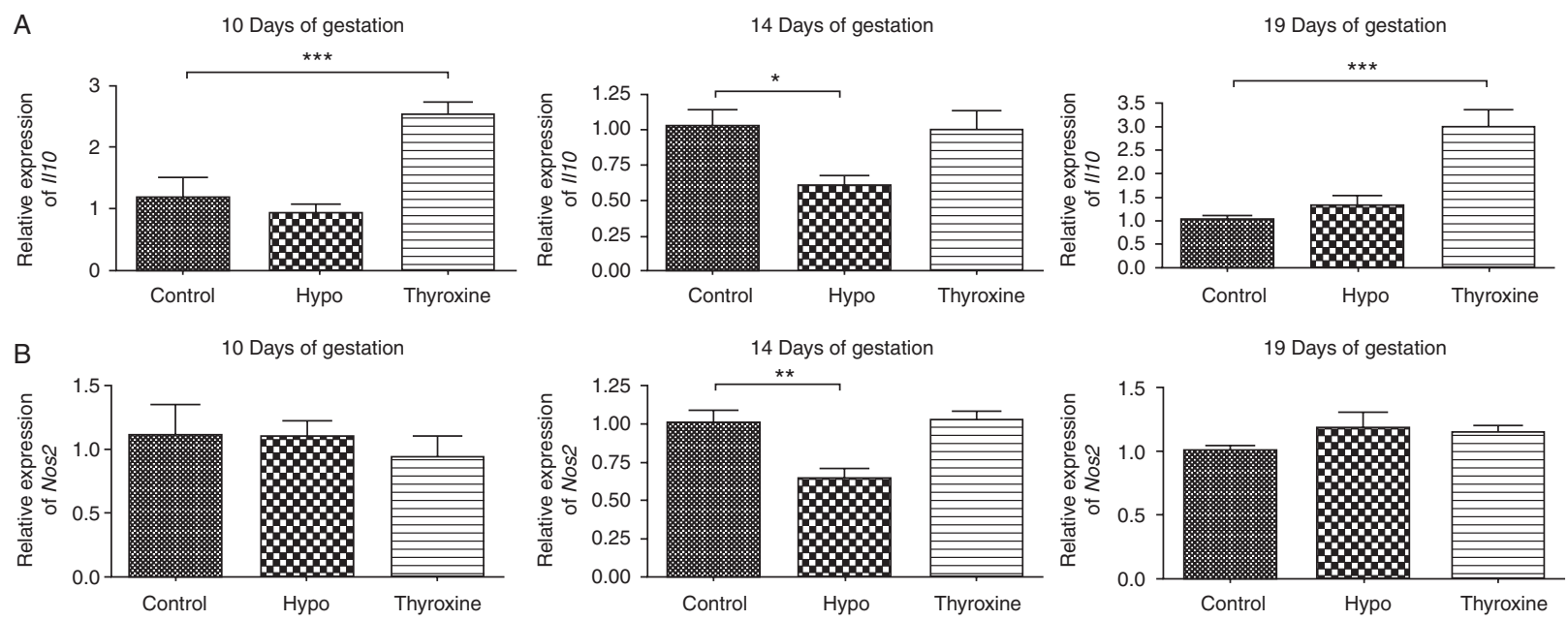

Figure 7 Relative expression of gene transcripts for $I / 10$ (A) and Nos2 (B) (mean \pm s.D.) in the placentas of pregnant rats from the control, hypothyroid, and thyroxine-treated groups at 10,14 , and 19 days of gestation $\left(* P<0.05,{ }^{*} P<0.01\right.$, and $\left.* * * P<0.001\right)$. 
A

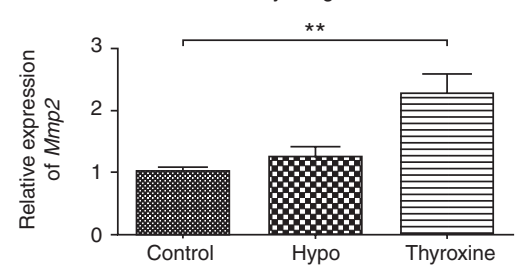

B

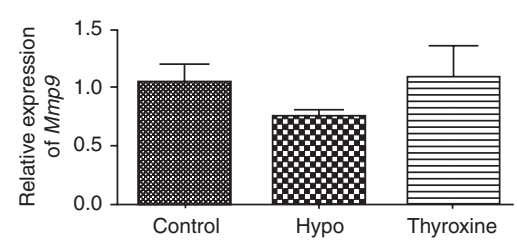

C

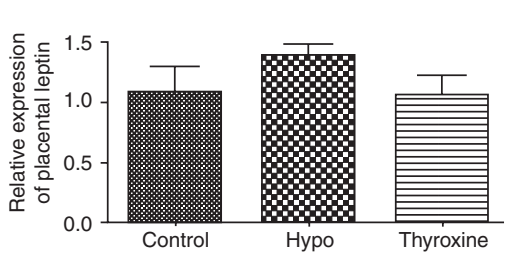

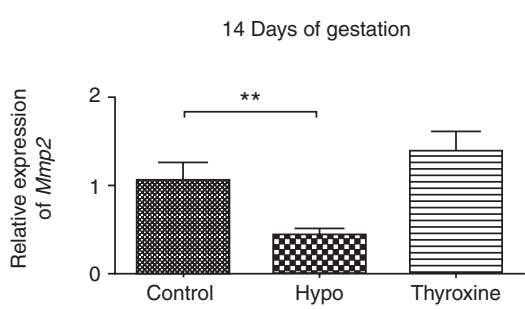

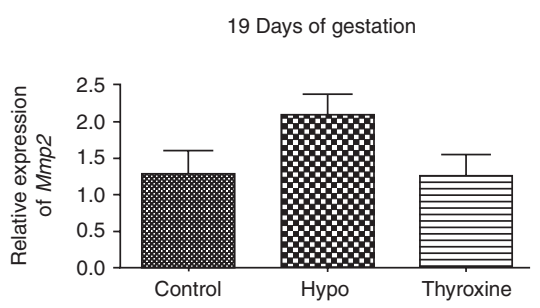

14 Days of gestation
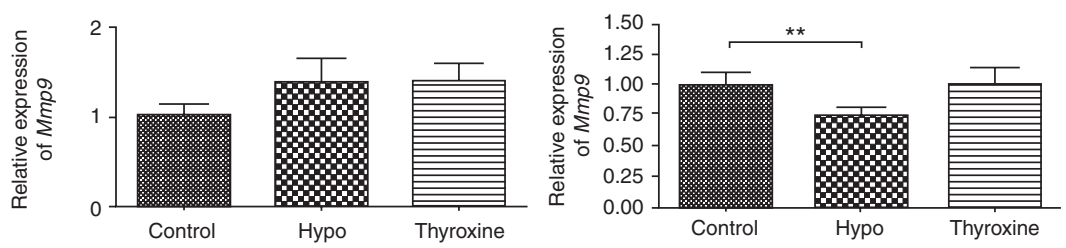

19 Days of gestation

19 Days of gestation

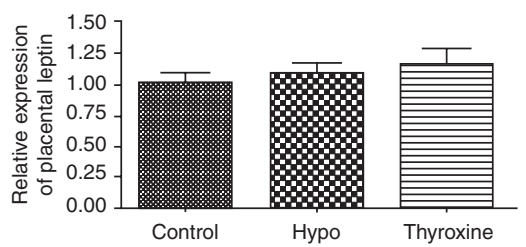

Figure 8 (A, B and C) Relative expression of gene transcripts for Mmp2 (A), Mmp9 (B), and placental leptin (C) (mean \pm s.D.) in placenta of pregnant rats from the control, hypothyroid, and thyroxine-treated groups at 10,14 , and 18 days of gestation $(* P<0.05)$.

\section{Gene expression of MMP2 and MMP9}

Hypothyroid rats showed a decrease in the Mmp2 mRNA expression at 14 days of gestation compared with the control rats $(P<0.05$; Fig. $8 \mathrm{~A})$. The $\mathrm{T}_{4}$-treated rats, however, showed an increase in the mRNA expression of Mmp2 compared with the control rats at 10 days of gestation $(P<0.05$; Fig. $8 \mathrm{~A})$.

Hypothyroid rats also showed a decrease in Mmp9 mRNA expression compared with control rats at 18 days of gestation $(P<0.05$; Fig. $8 \mathrm{~B})$. The $\mathrm{T}_{4}$-treated group showed no differences in gene expression of $\mathrm{Mmp} 9$ compared with the control group in any of the gestational periods ( $P>0.05$; Fig. $8 \mathrm{~B})$.

\section{Gene expression of placental leptin}

Similar to the expression of Mmp2, hypothyroid rats showed a decrease in the mRNA expression of placental leptin compared with the control rats at 14 days of gestation $(P<0.05 ;$ Fig. $8 \mathrm{C})$. The $\mathrm{T}_{4}$-treated group showed no differences in the gene expression of placental leptin compared with the control group in any of the gestational periods ( $P>0.05$; Fig. $8 C$ ).

\section{Kinetics of intrauterine trophoblast migration}

At 16 and 17 days of gestation, the placental disks of the hypothyroid rats showed a reduction in the endovascular trophoblast invasion index compared with that of control rats ( $P<0.05$; Figs 6 and 7$)$. The same was also observed at 15 and 17 days of gestation in relation to the interstitial trophoblastic invasion index $(P<0.05$; Fig. 9 and 10$)$.

$A$ reduction in endovascular trophoblast invasion was observed in the $\mathrm{T}_{4}$-treated rats compared with the control group at 18 days of gestation $(P<0.05$; Fig. 9A), with no significant differences at other gestational ages

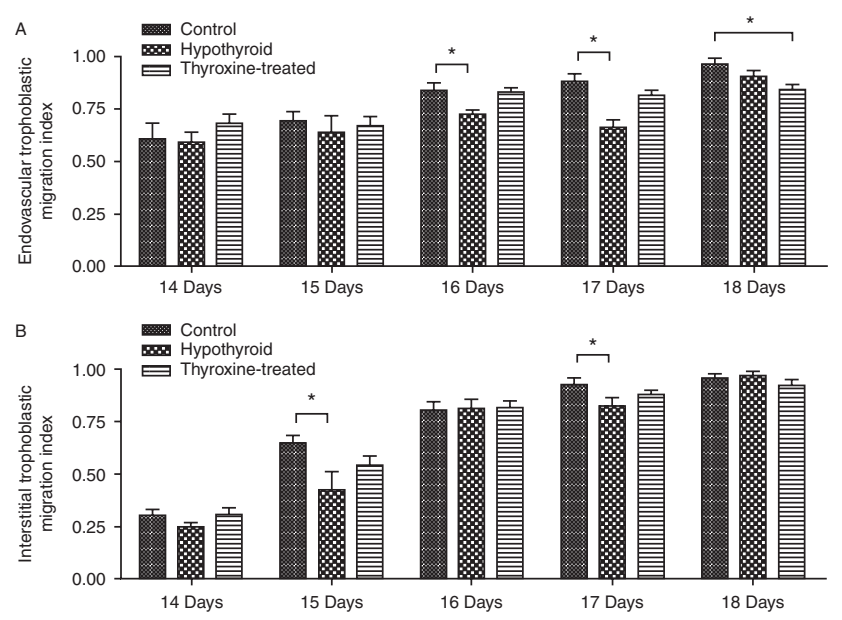

Figure 9 (A and B) Migration index (mean \pm s.D.) of endovascular (A) and interstitial (B) trophoblast cells in the decidua of pregnant rats of the control, hypothyroid, and thyroxine-treated groups at 14, 15, 16, 17, and 18 days of gestation $(* P<0.05)$. 


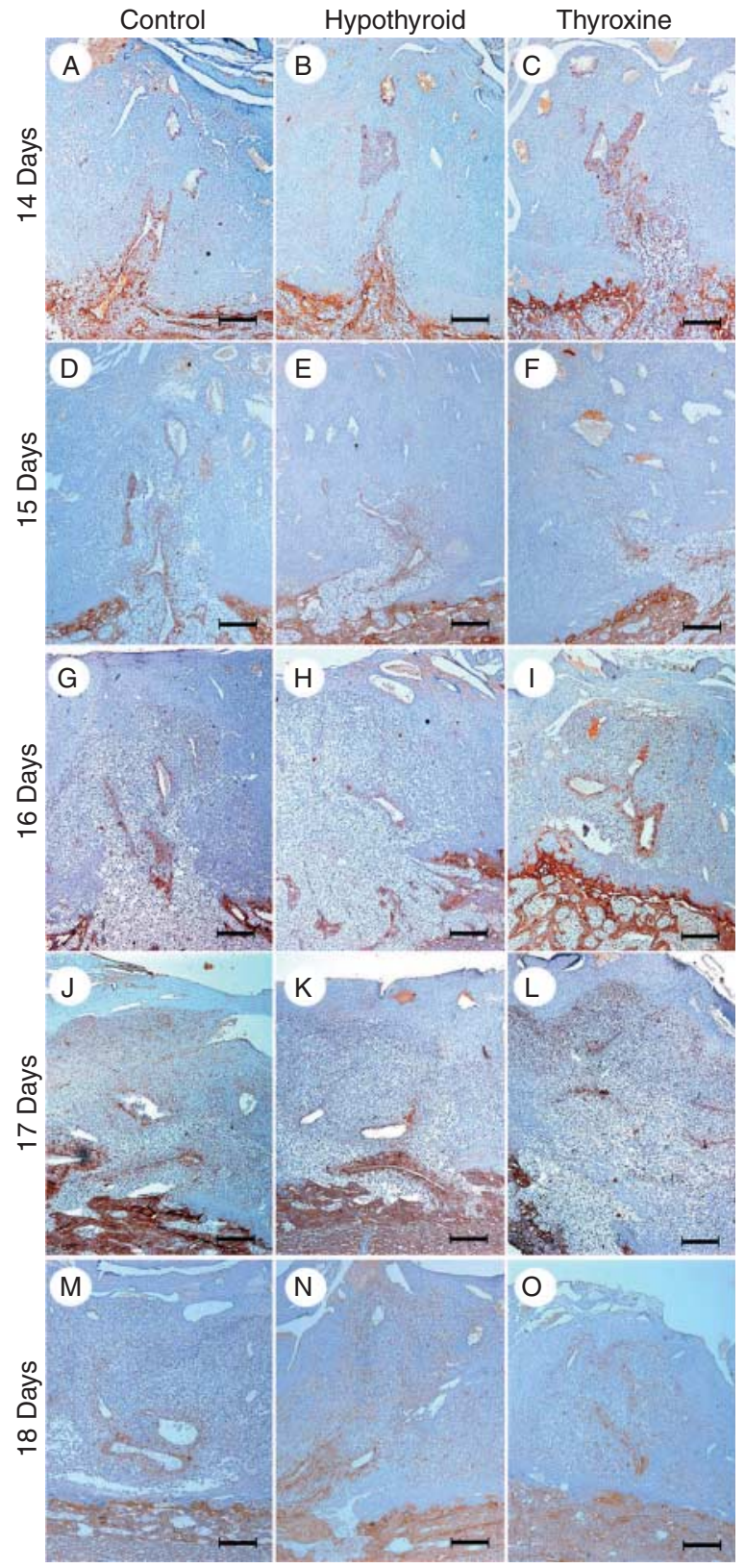

Figure $10(A, B, C, D, E, F, G, H, I, J, K, L, M, N$ and $O)$ Immunohistochemical images of the migration kinetics of interstitial and endovascular trophoblast cells in the decidua of pregnant rats of the control, hypothyroid, and thyroxine $\left(\mathrm{T}_{4}\right)$-treated groups at 14 (A, B and C), 15 (D, E and F), 16 (G, H and I), 17 (J, K and L), and 18 ( $\mathrm{M}, \mathrm{N}$ and $\mathrm{O}$ ) days of gestation. ( $\mathrm{G}, \mathrm{H}$ and $\mathrm{I})$ Lower endovascular trophoblast invasion in hypothyroid group $(\mathrm{H})$ compared with control (G) and $\mathrm{T}_{4}$-treated (I) groups at 16 days of gestation. (J, K and L) Lower interstitial trophoblastic invasion in the hypothyroid group $(\mathrm{K})$ compared with control $\left(\mathrm{J}\right.$ ) and $\mathrm{T}_{4}$-treated (L) groups at 17 days of gestation (streptavidin-biotin-peroxidase, Harris hematoxylin, scale bar $=360 \mu \mathrm{m})$.

$(P>0.05)$. Regarding interstitial trophoblastic invasion, the $\mathrm{T}_{4}$-treated group showed no significant differences compared with the control group in any of the gestational periods ( $P>0.05$; Fig. 9B).

\section{Discussion}

Hypothyroidism and excess of $\mathrm{T}_{4}$ affected the placental immune profile and the migration kinetics of trophoblast cells toward the decidua differently, and these effects were dependent on the gestational period. The changes observed in this study in the placental immunological profile in animals with hypothyroidism and excess of $\mathrm{T}_{4}$ mirror, at least in part, the fetal-placental changes seen in women and in animals with thyroid dysfunction (Shafrir et al. 1994, Morrish et al. 1997, Galton et al. 2001, Freitas et al. 2007, Souza et al. 2011, Silva et al. 2012). Our study also confirmed the hypothesis of Silva et al. (2012) that the migration of trophoblast cells is affected by thyroid dysfunction, particularly in hypothyroidism.

The high expression of the TIr2 gene observed in the placenta of the hypothyroid animals is in agreement with the increase in apoptosis observed by Silva et al. (2012) in rat placentas at 14 days of gestation. TLR2 expression induces apoptosis of trophoblast cells (Koga et al. 2009). In contrast, the lower Tlr4 mRNA levels in the placentas of the hypothyroid animals may have resulted in the decreased gene and/or protein expression of INFy, IL10, MIF, and NOS2 also observed in these animals. The expression and activation of TLR4 in trophoblast cells induces the expression and release of several pro- and anti-inflammatory cytokines (Koga et al. 2009). These results demonstrate that changes in the expression of TLRs in women and pregnant animals may result not only from infection-related processes (Koga et al. 2009) but also from changes in endocrine profiles.

Interestingly, 14 days of gestation, which is the time point at which there is greater apoptosis of trophoblast cells in hypothyroid animals (Silva et al. 2012) accompanied by increased gene expression of TIr2, was the time point at which there was a reduction in the gene and/or protein expression of the anti-inflammatory cytokines IL10 and NOS2 (Koga et al. 2009). Changes in the profile of these cytokines affect the fetal-placental environment (Toder et al. 2003). During fetal development, the establishment of an anti-inflammatory placental immune system is essential for the success of pregnancy (Coulam 2000, Toder et al. 2003). The reduced expression of NOS2 also promotes oxidative stress at the maternal-fetal interface, which is a cause of miscarriage, stillbirth, and premature birth (Rosario et al. 2008). The high serum levels of progesterone in the hypothyroid rats, as observed by Hatsuta et al. (2004), may also have favored the low NOS2 gene and protein expression levels observed. Mouse macrophages under the influence of a high dose of progesterone show a reduced expression of NOS2 (Miller et al. 1996).

The low level of INFy gene and protein expression observed in hypothyroid animals may also affect fetalplacental development. INFy directly influences the function of uterine natural killer cells, which are 
involved in immune function and placental vascular dynamics (Hu \& Cross 2010). Hypothyroid animals have alterations in placental vascularization (Silva et al. 2012). Furthermore, INFy stimulates the phagocytic activity of macrophages and trophoblast giant cells against microorganisms (Ashkar et al. 2000, Kim et al. 2005). Consequently, it is suggested that hypothyroidism may facilitate the pathogenic infection of a fetus and, thus, the development of pregnancy complications.

Hypothyroidism also reduced the invasion of both intrauterine endovascular trophoblast cells and interstitial trophoblast cells. The invasive trophoblast cells, which originate from the junction zone, participate in uterine vascular remodeling and in the secretion of the hormones (Ain et al. 2003, Caluwaerts et al. 2005, Konno et al. 2007). Cartwright et al. (1999) demonstrated that the motility and invasion of the trophoblast cells is highly dependent on the NOS produced by trophoblasts in vitro. Hypothyroid rats exhibit reduced mRNA and protein expression of NOS2 at 14 days of gestation. The precise coordination of the process of uterine vascular remodeling is critical to the success of pregnancy, because it ensures the proper delivery of nutrients to the fetus and prevents the exposure of the fetus to the deleterious effects of reactive oxygen species (Burton 2009). Thus, our results verify and explain, at least in part, the reproductive disorders found in hypothyroid rats (Silva et al. 2012). In previous research, our research group observed that pregnant hypothyroid rats subjected to the same protocol of induced thyroid dysfunction had reduced placental weight and smaller fetuses without showing any change in the total number of fetuses or in the fetal mortality rate (Silva et al. 2012). Thus, reduction in placental weight and smaller fetuses in hypothyroid rats can be a consequence of changes in the gene and protein expression of NOS2 and INFy, as these inflammatory mediators affect placental vascularization (Cartwright et al. 1999, Hu \& Cross 2010). In contrast, our research group observed that pregnant $\mathrm{T}_{4}$-treated rats had a higher conception rate without changing the fetal weight and viability (Freitas et al. 2007). It is suggested that the maintenance of the fetal weight and viability is a result of increased production of proangiogenic factors and placental lactogen by the placenta of these animals (J F Silva, N M Ocarino, R Serakides, unpublished data).

The hypothyroid animals showed reduced gene expression of Mmp2 and Mmp9 and placental leptin, unlike the $\mathrm{T}_{4}$-treated animals that had an increase in the mRNA expression of Mmp2. MMP2 and MMP9, which are mainly produced by trophoblast cells in the maternal-fetal interface, allow for cellular migration by degrading extracellular matrix proteins (Lala \& Chakraborty 2003, Varanou et al. 2006). These results are in agreement with the findings of Oki et al. (2004), which demonstrated that the deficiency of thyroid hormones in vitro reduces the mRNA expression of $M M P 2$ and $M M P 3$, fetal fibronectin and integrins by human extravillous trophoblasts. The expression of MMP2 and MMP9 has also been found to be stimulated by placental leptin (Gambino et al. 2012), corroborating with the results found in the present study.

Placental leptin is a key hormone in the placenta (Gambino et al. 2012). Research has shown that it induces the proliferation of trophoblast cells and inhibits apoptosis. Furthermore, it regulates the fetal growth and development by affecting the process of chondrogenesis and osteogenesis (Masuzaki et al. 1997, Señarís et al. 1997, Henson et al. 1998, Gambino et al. 2010, 2012, Miko et al. 2011). Hypothyroid rats show a reduction in the proliferation of trophoblast cells, an increase in apoptosis, and a reduction in fetal development (Silva et al. 2012). Thus, the reduction in the gene expression of placental leptin as well as of Mmp2 and Mmp9 in hypothyroid rats explains the failure in the migration kinetics of the trophoblast cells that was observed in these animals.

The higher plasma levels of progesterone in hypothyroid rats (Hatsuta et al. 2004) also reduce the migration of trophoblast cells. Progesterone reduces the secretion of gelatinase and MMP2 and MMP9 by trophoblasts (Shimonovitz et al. 1998, Dai et al. 2003, Spencer et al. 2004, Miko et al. 2011). The progesterone-induced blocking factor (PIBF), which has been identified in humans and mice, was originally described as a molecule induced by progesterone to mediate its effects during pregnancy (Szekeres-Bartho et al. 1985). It was found that PIBF reduces placental expression of leptin and its receptor, showing another route by which progesterone also affects the trophoblastic invasion (Miko et al. 2011).

Excess of $\mathrm{T}_{4}$ promoted an anti-inflammatory environment in the middle of gestation. It reduced the expression of the genes encoding TNF and MIF, which are pro-inflammatory cytokines, in addition to increasing the expression of IL10 and NOS2. Although we have not observed changes in the expression of TLR2 and TLR4 in the $\mathrm{T}_{4}$-treated animals, further research to evaluate the expression of other TLRs is necessary. Other TLRs such as TLR3, TLR6, and TLR9 are also expressed by trophoblast cells and can stimulate the release of inflammatory cytokines (Koga et al. 2009). The lower expression of TNF observed in $\mathrm{T}_{4}$-treated animals may be due to reduced Mif gene expression. MIF, directly or indirectly through its receptor $\mathrm{CD} 74$, promotes the expression of a variety of pro-inflammatory cytokines, including TNF (Faria et al. 2010, Cardaropoli et al. 2012).

We suggest that the increased gene and protein expression of MIF and INFy in $\mathrm{T}_{4}$-treated animals at 19 days of gestation may be related to the preterm delivery observed in these animals (Navas et al. 2011). Delivery is characterized by an influx of inflammatory cells into the myometrium (Koga et al. 2009). This pro-inflammatory environment promotes the contraction of the uterus, the expulsion of the fetus, and the rejection of the placenta (Koga et al. 2009). Delivery also occurs in a hypoxic environment, being that low oxygen tension 
in vitro enhances the expression of MIF mRNA and protein in explants of chorionic villi (letta et al. 2007).

The lower endovascular trophoblast invasion observed in the $\mathrm{T}_{4}$-treated rats at 18 days of gestation may also be related to the premature delivery observed in these animals (Navas et al. 2011). This may be explained by the occurrence of death and/or removal of invasive trophoblast cells during and after delivery (Soares et al. 2012). This is important not only for the proper delivery of the fetus but also for the health of the mother and the success of subsequent pregnancies (Soares et al. 2012). Increased intrauterine invasion of trophoblast cells during late gestation accompanied by a failure of their removal from the uterine decidua, in contrast to what was observed in $\mathrm{T}_{4}$-treated rats, is a pertinent cause of retained placenta, dystocia, and post partum hemorrhage in women and domestic animal species and can be fatal (Tantbirojn et al. 2008, Rosario et al. 2009).

We conclude that hypothyroidism affects the maternal immune function by compromising the development of an anti-inflammatory environment in the maternal-fetal interface and affects intrauterine trophoblast migration. Hypothyroidism affects the expression of the TIr2 and TIr4 genes and reduces the gene and/or protein expression of IL10, Nos2, Inf $\gamma$, Mif, Mmp2 and Mmp9, and of placental leptin in experimental animals. Excess of $\mathrm{T}_{4}$, in contrast, promotes an anti-inflammatory environment in the middle of gestation by reducing the gene expression of TNF and MIF and increasing the gene and/or protein expression of IL10 and NOS2. Excess of $\mathrm{T}_{4}$ also increases the gene expression of MMP2 in the middle of pregnancy and the gene and protein expression of INFy and MIF in the late pregnancy.

\section{Declaration of interest}

The authors declare that there is no conflict of interest that could be perceived as prejudicing the impartiality of the research reported.

\section{Funding}

This work was supported by grants from Fundação de Amparo à Pesquisa de Minas Gerais (Fapemig), Conselho Nacional de Desenvolvimento Científico e Tecnológico (CNPq), and Pró-Reitoria de Pesquisa (PRPq) of the Universidade Federal de Minas Gerais.

\section{References}

Ain R, Canham LN \& Soares MJ 2003 Gestation stage-dependent intrauterine trophoblastcell invasion in the rat and mouse: novel endocrine phenotype and regulation. Developmental Biology 260 176-190. (doi:10.1016/S0012-1606(03)00210-0)

Amin MA, Volpert OV, Woods JM, Kumar P, Harlow LA \& Koch AE 2003 Migration inhibitory factor mediates angiogenesis via mitogen-activated protein kinase and phosphatidylinositol kinase. Circulation Research 93 321-329. (doi:10.1161/01.RES.0000087641.56024.DA)
Ashkar AA, Di Santo JP \& Croy BA 2000 Interferon y contributes to initiation of uterine vascular modification decidual integrity and uterine natural killer cell maturation during normal murine pregnancy. Journal of Experimental Medicine 192 259-269. (doi:10.1084/jem.192.2.259)

Burton GJ 2009 Oxygen, the Janus gas; its effects on human placental development and function. Journal of Anatomy 215 27-35. (doi:10.1111/j.1469-7580.2008.00978.x)

Caluwaerts S, Vercruysse L, Luyten C \& Pijnenborg R 2005 Endovascular trophoblast invasion and associated structural changes in uterine spiral arteries of the pregnant rat. Placenta 26 574-584. (doi:10.1016/ j.placenta.2004.09.007)

Cardaropoli S, Paulesu L, Romagnoli R, letta F, Marzioni D, Castellucci M, Rolfo A, Vasario E, Piccoli E \& Todros T 2012 Macrophage migration inhibitory factor in fetoplacental tissues from preeclamptic pregnancies with or without fetal growth restriction. Clinical \& Developmental Immunology 2012 639342. (doi:10.1155/2012/639342)

Cartwright JE, Holden DP \& Whitley GS 1999 Hepatocyte growth factor regulates human trophoblast motility and invasion: a role for nitric oxide. Clinical \& Developmental Immunology 128 181-189. (doi:10.1038/sj. bjp.0702757)

Chakraborty D, Rumi MA, Konno T \& Soares MJ 2011 Natural killer cells direct hemochorial placentation by regulating hypoxia-inducible factor dependent trophoblast lineage decisions. PNAS 108 16295-16300. (doi:10.1073/pnas.1109478108)

Coulam CB 2000 Understanding the immunobiology of pregnancy and applying it to treatment of recurrent pregnancy loss. Early Pregnancy 4 19-29.

Dai B, Cao Y, Liu W, Li S, Yang Y, Chen D \& Duan E 2003 Dual roles of progesterone in embryo implantation in mouse. Endocrine 21 123-132.

Faria MR, Hoshida MS, Ferro EA, letta F, Paulesu L \& Bevilacqua E 2010 Spatiotemporal patterns of macrophage migration inhibitory factor (Mif) expression in the mouse placenta. Reproductive Biology and Endocrinology 8 95. (doi:10.1186/1477-7827-8-95)

Flo TH, Ryan L, Latz E, Takeuchi O, Monks BG, Lien E, Halaas O, Akira S, Skjåk-Braek G, Golenbock DT et al. 2002 Involvement of Tolllike receptor (TLR) 2 and TLR4 in cell activation by mannuronic acid polymers. Journal of Biological Chemistry 277 35489-35495. (doi:10.1074/jbc.M201366200)

Freitas ES, Leite ED, Souza CA, Ocarino NM, Ferreira E, Cassali GD, Gomes MG \& Serakides R 2007 Histomorphometry and expressions of Cdc47 and Caspase-3 in hyperthyroid rats uteri and placentas during gestation and postpartum associated with fetal development. Reproduction, Fertility, and Development 19 498-509. (doi:10.1071/ RD06086)

Galton VA, Martinez E, Hernandez A, St Germain EA, Bates JM \& St Germain DL 2001 The type 2 iodothyronine deiodinase is expressed in the rat uterus and induced during pregnancy. Endocrinology 142 2123-2128. (doi:10.1210/endo.142.5.8169)

Gambino YP, Maymó JL, Pérez-Pérez A, Dueñas JL, Sánchez-Margalet V, Calvo JC \& Varone CL 2010 17 $\beta$-Estradiol enhances leptin expression in human placental cells through genomic and nongenomic actions. Biology of Reproduction 83 42-51. (doi:10.1095/biolreprod.110.083535)

Gambino YP, Maymó JL, Pérez Pérez A, Calvo JC, Sánchez-Margalet V \& Varone CL 2012 Elsevier Trophoblast Research Award lecture: Molecular mechanisms underlying estrogen functions in trophoblastic cells - focus on leptin expression. Placenta 33 S63-S70. (doi:10.1016/j.placenta. 2011.12.001)

Hammer A 2011 Immunological regulation of trophoblast invasion. Journal of Reproductive Immunology 90 21-28. (doi:10.1016/j.jri. 2011.05.001)

Hatsuta M, Abe K, Tamura K, Ryuno T, Watanabe G, Taya K \& Kogo H 2004 Effects of hypothyroidism on the estrus cycle and reproductive hormones in mature female rat. European Journal of Pharmacology 486 343-348. (doi:10.1016/j.ejphar.2003.12.035)

Henson MC, Swan KF \& O'Neil JS 1998 Expression of placental leptin and leptin receptor transcripts in early pregnancy and at term. Obstetrics \& Gynecology 92 1020-1028.

Hu D \& Cross JC 2010 Development and function of trophoblast giant cells in the rodent placenta. International Journal of Developmental Biology 54 341-354. (doi:10.1387/ijdb.082768dh)

letta F, Wu Y, Romagnoli R, Soleymanlou N, Orsini B, Zamudio S, Paulesu L \& Caniggia I 2007 Oxygen regulation of macrophage migration 
inhibitory factor in human placenta. American Journal of Physiology. Endocrinology and Metabolism 292 E272-E280. (doi:10.1152/ajpendo. 00086.2006)

Kim S, Lee DS, Watanabe K, Furuoka H, Suzuki H \& Watarai M 2005 Interferon-y promotes abortion due to Brucella infection in pregnancy mice. BMC Microbiology 5 22. (doi:10.1186/1471-2180-5-22)

Knöfler M 2010 Critical growth factors and signalling pathways controlling human trophoblast invasion. International Journal of Developmental Biology 54 269-280. (doi:10.1387/ijdb.082769mk)

Koga K \& Mor G 2010 Toll-like receptors at the maternal-fetal interface in normal pregnancy and pregnancy disorders. American Journal of Reproductive Immunology 63 587-600. (doi:10.1111/j.1600-0897. 2010.00848.x)

Koga K, Aldo PB \& Mor G 2009 Toll-like receptors and pregnancy: trophoblast as modulators of the immune response. Journal of Obstetrics and Gynaecology Research 35 191-202. (doi:10.1111/j.1447-0756. 2008.00963.x)

Konno T, Rempel LA, Arroyo JÁ \& Soares MJ 2007 Pregnancy in the brown Norway rat: a model for investigating the genetics of placentation. Biology of Reproduction 76 709-718. (doi:10.1095/biolreprod.106.056481)

Lala PK \& Chakraborty C 2003 Factors regulating trophoblast migration and invasiveness: possible derangements contributing to pre-eclampsia and fetal injury. Placenta 24 575-587. (doi:10.1016/S0143-4004(03) 00063-8)

Masuzaki H, Ogawa $Y$, Sagawa N, Hosoda K, Matsumoto T, Mise H, Nishimura H, Yoshimasa Y, Tanaka I, Mori T \& Nakao K 1997 Nonadipose tissue production of leptin: leptin as a novel placentaderived hormone in humans. Nature Medicine 3 1029-1033.

Miko E, Halasz M, Jericevic-Mulac B, Wicherek L, Arck P, Arató G, Skret Magierlo J, Rukavina D \& Szekeres-Bartho J 2011 Progesterone-induced blocking factor (PIBF) and trophoblast invasiveness. Journal of Reproductive Immunology 90 50-57. (doi:10.1016/j.jri.2011.03.005)

Miller L, Alley EW, Murphy WJ, Russell SW \& Hunt JS 1996 Progesterone inhibits inducible nitric oxide synthase gene expression and nitric oxide production in murine macrophages. Journal of Leukocyte Biology 59 442-450.

Morrish DW, Dakour J, Li H, Xiao J, Miller R, Sherburne R, Berdan RC \& Guilbert LJ 1997 In vitro cultured human term cytotrophoblast: a model for normal primary epithelial cells demonstrating a spontaneous differentiation programme that requires EGF for extensive development of syncytium. Placenta 18 577-585. (doi:10.1016/0143-4004(77)90013-3)

Murphy SP, Choi JC \& Holtz R 2004 Regulation of major histocompatibility complex class II gene expression in trophoblast cells. Reproductive Biology and Endocrinology 2 52-59. (doi:10.1186/1477-7827-2-52)

Navas PB, Motta AB, Hapon MB \& Jahn GA 2011 Hyperthyroidism advances luteolysis in the pregnant rat through changes in prostaglandin balance. Fertility and Sterility 96 1008-1014. (doi:10.1016/j.fertnstert. 2011.07.010)

Oki N, Matsuo H, Nakago S, Murakoshi H, Laoag-Fernandez JB \& Maruo T 2004 Effects of 3,5,3'-triiodothyronine on the invasive potential and the expression of the integrins and matrix metalloproteinases in cultured early placental extravillous trophoblasts. Journal of Clinical Endocrinology and Metabolism 89 5213-5221. (doi:10.1210/ jc.2004-0352)

Raghupathy R 1997 Th1-type immunity is incompatible with successful pregnancy. Immunology Today 18 478-482. (doi:10.1016/S0167-5699 (97)01127-4)

Rosario GX, Konno T \& Soares MJ 2008 Maternal hypoxia activates endovascular trophoblast cell invasion. Developmental Biology 314 362-375. (doi:10.1016/j.ydbio.2007.12.007)

Rosario GX, Ain R, Konno T \& Soares MJ 2009 Intrauterine fate of invasive trophoblast cells. Placenta 30 457-463. (doi:10.1016/j.placenta.2009. 02.008)

Señarís R, Garcia-Caballero T, Casabiell X, Gallego R, Castro R, Considine RV, Dieguez C \& Casanueva FF 1997 Synthesis of leptin in human placenta. Endocrinology 138 4501-4504.

Serakides R, Nunes VA, Nascimento EF, Ribeiro AFC \& Silva CM 2001 Foliculogênese e esteroidogênese ovarianas em ratas adultas hipertireóideas. Arquivos Brasileiros de Endocrinologia e Metabologia 45 258-264. (doi:10.1590/S0004-27302001000300008)
Shafrir E, Barash V, Zederman R, Kissilevitz R \& Diamant YZ 1994 Modulation of fetal and placental metabolic pathways in response to maternal thyroid and glucocorticoid hormone excess. Israel Journal of Medical Sciences 30 32-41.

Shimonovitz S, Hurwitz A, Hochner-Celnikier D, Dushnik M, Anteby E \& Yagel S 1998 Expression of gelatinase B by trophoblast cells: downregulation by progesterone. American Journal of Obstetrics and Gynecology 178 457-461. (doi:10.1016/S0002-9378(98)70420-X)

Silva CM, Serakides R, Oliveira TS, Ocarino NM, Nascimento EF \& Nunes VA 2004 Histomorfometria e histoquímica dos ovários, tubas e útero de ratas hipotireóideas em metaestro-diestro. Arquivo Brasileiro de Medicina Veterinária e Zootecnia 56 628-639. (doi:10.1590/S010209352004000500010)

Silva JF, Vidigal PN, Galvão DD, Boeloni JN, Nunes PP, Ocarino NM, Nascimento EF \& Serakides R 2012 Fetal growth restriction in hypothyroidism is associated with changes in proliferative activity, apoptosis and vascularisation of the placenta. Reproduction, Fertility, and Development 24 923-931. (doi:10.1071/RD11219)

Soares MJ, Chakraborty D, Karim Rumi MA, Konno T \& Renaud SJ 2012 Rat placentation: an experimental model for investigating the hemochorial maternal-fetal interface. Placenta 33 233-243. (doi:10.1016/j.placenta. 2011.11.026)

Souza CA, Ocarino NM, Silva JF, Boeloni JN, Nascimento EF, Silva IJ, Castro RD, Moreira LP, Almeida FR, Chiarini-Garcia H et al. 2011 Administration of thyroxine affects the morphometric parameters and VEGF expression in the uterus and placenta and the uterine vascularization but does not affect reproductive parameters in gilts during early gestation. Reproduction in Domestic Animals 46 e7-e16. (doi:10.1111/ j.1439-0531.2010.01615.x)

Spencer TE, Burghardt RC, Johnson GA \& Bazer FW 2004 Conceptus signals for establishment and maintenance of pregnancy. Animal Reproduction Science 83 537-550. (doi:10.1016/j.anireprosci.2004.04.014)

Szekeres-Bartho J, Kilaŕ F, Falkay G, Csernus V, Török A \& Pacsa AS 1985 The mechanism of the inhibitory effect of progesterone on lymphocyte cytotoxicity: I. Progesterone-treated lymphocytes release a substance inhibiting cytotoxicity and prostaglandin synthesis. American Journal of Reproductive Immunology 9 15-18.

Tantbirojn P, Crum CP \& Parast MM 2008 Pathophysiology of placenta creta: the role of decidua and extravillous trophoblast. Placenta 29 639-645. (doi:10.1016/j.placenta.2008.04.008)

Toder V, Fein A, Carp H \& Torchinsky A 2003 TNF- $\alpha$ in pregnancy loss and embryo maldevelopment: a mediator of detrimental stimuli or a protector of the fetoplacental unit? Journal of Assisted Reproduction and Genetics 20 73-81. (doi:10.1023/A:1021740108284)

Varanou A, Withington SL, Lakasing L, Williamson C, Burton GJ \& Hemberger M 2006 The importance of cysteine cathepsin proteases for placental development. Journal of Molecular Medicine 84 305-317. (doi:10.1007/s00109-005-0032-2)

Viganò P, Cintorino M, Schatz F, Lockwood CJ \& Arcuri F 2007 The role of macrophage migration inhibitory factor in maintaining the immune privilege at the fetal-maternal interface. Seminars in Immunopathology 29 135-150. (doi:10.1007/s00281-007-0074-3)

Weinberg ED 1987 Pregnancy-associated immune suppression: risks and mechanisms. Microbial Pathogenesis 3 393-397. (doi:10.1016/08824010(87)90009-X)

Xie F, Turvey SE, Williams MA, Mor G \& von Dadelszen P 2010 Toll-like receptor signaling and pre-eclampsia. American Journal of Reproductive Immunology 63 7-16. (doi:10.1111/j.1600-0897.2009.00745.x)

Zhang J, Sun R, Wei H, Wu D \& Tian Z 2007 Toll-like receptor 3 agonist enhances IFN- $\gamma$ and TNF- $\alpha$ production by murine uterine NK cells. International Immunopharmacology 7 588-596. (doi:10.1016/j.intimp. 2006.12.014)

Received 12 August 2013

First decision 4 September 2013

Revised manuscript received 10 February 2014

Accepted 17 February 2014 